\title{
Organic matter and copper mineralization at White Pine, Michigan, U.S.A.
}

\author{
Jeffrey L. Mauk ${ }^{\mathrm{a}}$ and G.B. Hieshima ${ }^{\mathrm{b}, \alpha}$ \\ ${ }^{a}$ Department of Geological Sciences, University of Michigan, Ann Arbor, MI 48109. USA \\ ${ }^{\mathrm{b}}$ Geology Department, Indiana University, Bloomington, IN 47405, USA
}

(Received May 21, 1991; revised and accepted February 20, 1992)

\begin{abstract}
Mauk, J.L. and Hieshima, G.B., 1992. Organic matter and copper mineralization at White Pine, Michigan, U.S.A. In: P.A. Meyers, L.M. Pratt and B. Nagy (Guest-Editors), Geochemistry of Metalliferous Black Shales. Chem. Geol., 99: 189211.
\end{abstract}

Indigenous and exogenous organic matter in sediments of the North American Midcontinent Rift were involved in precipitation of $\mathrm{Cu}$-bearing minerals during main- and second-stage mineralization events at White Pine, Michigan. Samples of the Proterozoic Nonesuch Formation from the White Pine mine and adjacent areas were investigated petrographically and geochemically in order to determine the influence of organic matter on the precipitation of $\mathrm{Cu}$ and to determine whether mineralization influenced thermal maturity of organic matter.

During main-stage mineralization, introduction of cupriferous fluids into the lower Nonesuch Fm. formed Cu-bearing sulfides by replacement of pyrite. Sulfur may have been added to the system via abiogenic sulfate reduction, with organic matter providing a direct source of reducing potential. In basal ore horizons where all sulfide had been incorporated into chalcocite during main-stage mineralization, native $\mathrm{Cu}$ also precipitated locally, with organic matter presumably acting as a direct reductant.

Later compressional faulting at White Pine provided conduits for additional cupriferous fluids; these fluids deposited second-stage $\mathrm{Cu}$ mineralization. Inclusions of liquid petroleum and solid pyrobitumen in veins filling fractures associated with compressional faults record migration of petroleum into the White Pine district from the deeper, hotter, axis of the rift penecontemporaneous with second-stage fluids. Some of this petroleum may have acted as a reductant during precipitation of native $\mathrm{Cu}$ in basal ore horizons.

Biomarker compositions of bitumens and isotopic compositions of individual $n$-alkanes from petroleums and bitumens suggest that these materials were all derived from organic matter deposited during sedimentation of the Nonesuch Fm.. Biomarker data demonstrate that bitumens from the White Pine area have significantly higher levels of thermal maturity than bitumens from unmineralized strata outside the mine area. Therefore, Cu mineralization at White Pine coincides with a thermal anomaly. Seep petroleums from the northeast and southwest domains of the mine contain different $n$-alkane distributions; we propose that this difference reflects elevated thermal maturity of seep petroleums spatially associated with second-stage mineralization in the southwestern domain of the mine.

\section{Introduction}

Located in the Lake Superior portion of the Midcontinent Rift System (Fig. 1), White Pine

Correspondence to: J.L. Mauk, Department of Geological Sciences, University of Michigan, Ann Arbor, MI 48109 , USA.

${ }^{\alpha}$ Present address: Exxon Production Research, P.O. Box 2189, Houston, TX 77252-2189, USA. is a major sediment-hosted stratiform $\mathrm{Cu}$ deposit within the 1.1-Ga Nonesuch Fm. which also contains petroleum derived from these Proterozoic rocks. Previous studies at White Pine have concentrated on either petroleum (e.g., Eglinton et al., 1964; Meinschein et al., 1964; Hoering, 1976; Pratt et al., 1991) or $\mathrm{Cu}$ mineralization (e.g., White and Wright, 1954, 1966; White, 1960; Carpenter, 1963; Brown, 


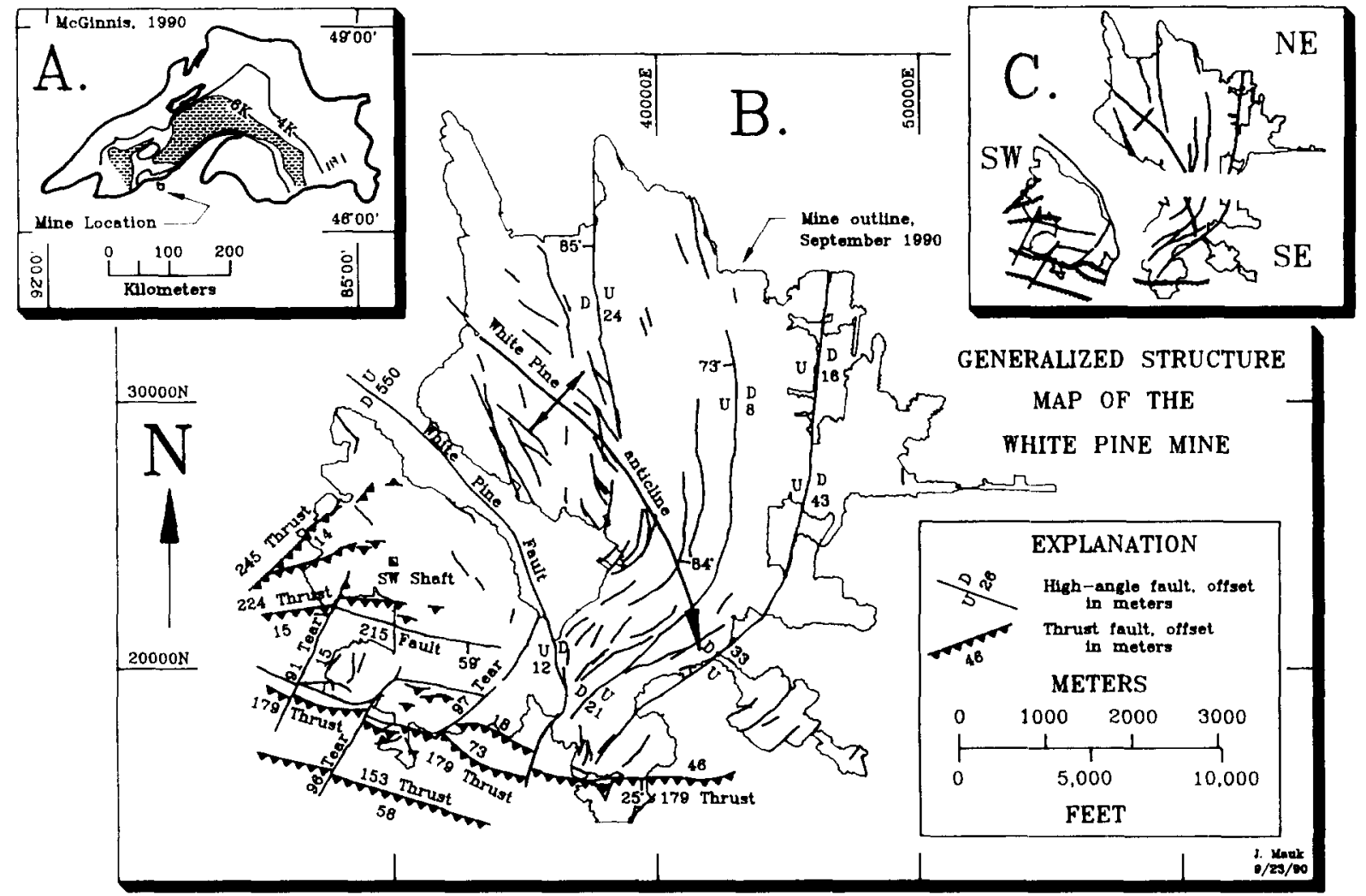

Fig. 1. A. General location of the White Pine mine showing thickness of Midcontinent Rift fill under Lake Superior (modified from McGinnis, 1990).

B. Generalized structure map of the White Pine mine.

C. Exploded map of the White Pine mine showing the three structural domains of the mine.

1971; Burnie et al., 1972; Wiese, 1973), although a few authors have speculated on possible relations between organic matter and mineralization (Brady, 1960; Hamilton, 1967; Kelly and Nishioka, 1985; Ho et al., 1990). This paper establishes the relative timing of petroleum migration in the vicinity of White Pine, describes organic matter at the deposit, and also discusses possible relations between organic matter and $\mathrm{Cu}$ mineralization within three stratigraphic units in the mine area.

Recent work in sediment-hosted ore deposits suggests organic matter can promote precipitation of metallic minerals by two pro- cesses. Oxidation of organic matter can be coupled to reduction of an oxidized species, by reactions such as that shown in the following equation (e.g., Leventhal, 1986):

$$
\begin{gathered}
4 \mathrm{CuCl}_{2}{ }^{-}+\mathrm{CH}_{2} \mathrm{O}+\mathrm{H}_{2} \mathrm{O} \rightarrow \\
4 \mathrm{Cu}^{0}+\mathrm{CO}_{2}+4 \mathrm{H}^{+}+8 \mathrm{Cl}^{-}
\end{gathered}
$$

Oxidation of 1 molecule of $\mathrm{CH}_{2} \mathrm{O}$ to $\mathrm{CO}_{2}$ can lead to reduction of 4 atoms of $\mathrm{Cu}^{+}$to $\mathrm{Cu}^{0}$.

Alternatively, organic matter can be oxidized by reduction of sulfate to sulfide that can then react with metal species (e.g., Berner, $1984)$ : 
$\mathrm{SO}_{4}^{2-}+2 \mathrm{CH}_{2} \mathrm{O} \rightarrow$

$$
2 \mathrm{HCO}_{3}^{-}+\mathrm{HS}^{-}+\mathrm{H}^{+}
$$

$\mathrm{HS}^{-}+2 \mathrm{CuCl}_{2}^{-} \rightleftharpoons \mathrm{Cu}_{2} \mathrm{~S}+\mathrm{H}^{+}+4 \mathrm{Cl}^{-}$

Although reaction ( 3 ) is written above to form chalcocite, pyrite commonly forms during early diagenesis by reaction of hydrogen sulfide with ferric iron. This process can be mediated by bacteria at temperatures below $90^{\circ} \mathrm{C}$ (e.g., Berner, 1984), or can occur abiogenically at higher temperatures, though the lower limit for abiogenic sulfate reduction remains controversial (e.g., Ohmoto and Lasaga, 1982; Trudinger et al., 1985; Machel, 1989). Influx of cupriferous brines can subsequently transform pyrite to chalcocite, resulting in formation of 2 mol of chalcocite for each mole of precursor pyrite:

$$
\begin{aligned}
\mathrm{C}_{6} \mathrm{H}_{12}+ & 12 \mathrm{CuCl}_{2}^{-}+3 \mathrm{FeS}_{2} \rightleftharpoons 6 \mathrm{Cu}_{2} \mathrm{~S} \\
+ & 3 \mathrm{Fe}^{2+}+6 \mathrm{H}^{+}+24 \mathrm{Cl}^{-}+\mathrm{C}_{6} \mathrm{H}_{6}
\end{aligned}
$$

However, as shown in reaction (4), the reduction of sulfur from $\mathrm{S}^{-}$to $\mathrm{S}^{2-}$ requires a concomitant oxidation reaction, which may have involved organic carbon. Both reaction schemes may have been operative at White Pine. In the first, organic matter has a direct role in precipitation of ore minerals (native $\mathrm{Cu}$ ). In the second, organic matter plays either a direct role, when sulfide reacts with cuprous ions to form chalcocite, or an indirect and direct role, when pyrite forms first and is later replaced to form $\mathrm{Cu}$-sulfides.

Conversely, mineralization can influence the composition and occurrence of organic matter. Hydrothermal processes associated with the influx of hot brines can produce petroleums similar to those evolved during burial maturation of kerogen (e.g., Simoneit, 1990). $\mathrm{Cu}$ mineralization in the Kupferschiefer deposits of Poland is interpreted to result from thermochemical sulfide production with organic matter acting as the source for hydrogen equivalents (Püttmann et al., 1988, 1989; Püttmann and Gobel, 1990).

\section{Geologic setting}

\subsection{Regional stratigraphy}

The North American. Midcontinent Rift in the Lake Superior basin contains up to $15 \mathrm{~km}$ of rift-related volcanic rocks and up to $10 \mathrm{~km}$ of overlying sediments (Behrendt et al., 1988; Cannon et al., 1989; McGinnis, 1990). Overall stratigraphy near White Pine consists of a basal 3-5 km of mafic to intermediate flows of the Portage Lake lava series and the "unnamed" Fm. Davis and Paces (1990) present $\mathrm{U}-\mathrm{Pb}$ zircon ages from two pegmatoids within Portage Lake lavas in the Keweenaw Peninsula of $1094.0 \pm 1.6$ and 1096.2 $\pm 1.8 \mathrm{Ma}$. Interstratified with and overlying the "unnamed" Fm. is the Copper Harbor Conglomerate, a red sandstone and conglomeratic unit up to $2 \mathrm{~km}$ thick, with an age of $1087.2 \pm 1.6 \mathrm{Ma}$, based on $\mathrm{U}-\mathrm{Pb}$ analyses of zircon from an intraformational andesite flow (Davis and Paces, 1990). Overlying the Copper Harbor Conglomerate are dominantly green to gray siltstones and shales of the 40-300-m-thick Nonesuch Fm. The data of Chaudhuri and Faure (1967) yield a Rb-Sr, whole-rock age of Nonesuch Fm. sediments of $1044 \pm 45 \mathrm{Ma}$ [recalculated using model-3 regression on Isoplot (Ludwig, 1990) and decay constants of Steiger and Jäger (1977) ], although this date may be too old because of inherited ${ }^{87} \mathrm{Sr}$. Up to $4 \mathrm{~km}$ of red sandstones of the Freda Fm. overlie the Nonesuch Fm. The age of the Freda Fm. can be constrained by the age of the Bear Lake andesite, an extrusive or subvolcanic dome within the sequence, that has been dated at $1062 \pm 34$ Ma [K-Ar, biotite (White, 1968), recalculated using decay constants of Steiger and Jäger (1977) ]. The Copper Harbor, Nonesuch and Freda Formations form the Oronto Group, whose stratigraphy and sedimentation has been investigated by other workers (Daniels, 1982; Elmore, 1983a, b; Elmore et al., 1989). The rocks described above lie on the upper plate of the Keweenaw fault (Hinze et al., 1990); oxi- 
dized sandstones of the Proterozoic Jacobsville Sandstone, which is believed to be younger than the Oronto Group, lies to the south of the Keweenaw fault (Kalliokoski, 1982).

\subsection{Mine area stratigraphy and units analyzed}

Only the basal 1-4 m of the Nonesuch Fm. within the White Pine mine contain economic concentrations of $\mathrm{Cu}$ minerals (Fig. 2). The lower Nonesuch Fm. consists of alternating reduced and oxidized strata; oxidized strata contain $<1 \% \mathrm{Cu}$, whereas reduced strata contain $2-4 \% \mathrm{Cu}$ (Fig. 2). Six stratigraphic horizons contribute most of the $\mathrm{Cu}$ recovered from the mine. Four of these are black, relatively shaley units (the "lower transition" unit, the "domino" shale, the "upper transition" unit and the "thinly" shale); the other two are massive darkgray siltstones (DGM or the "dark-gray massive" siltstone and UZV or the "upper zone of values" siltstone). The "domino" shale is one of the units studied in this investigation (Fig. $3 a$ ), and we infer that data from this stratigraphic unit are applicable to other mineralized black shales in the mine.

The "stripey" shale, a black to dark-gray silty shale with mm-scale carbonate laminations parallel to bedding, occurs near the top of the lower Nonesuch Fm. The "stripey" shale and the overlying "marker" unit are two of the carbonate laminites containing relatively high amounts of organic carbon described by Imbus et al. (1988). Sample locations for the "stripey" shale are clustered (Fig. 3c) because this unit overlies the mined stratigraphy, and is therefore exposed underground only adjacent to major faults. The "stripey" shale contains no Cu-bearing minerals over most of the extent of the lower Nonesuch Fm. we have studied (from Houghton, Michigan, to the Michigan-Wisconsin border). However, it does contain $\mathrm{Cu}$-bearing minerals adjacent to some major faults, and as described below (p.194), this $\mathrm{Cu}$ mineralization is genetically related to a thrusting event at White Pine. Therefore samples of the "stripey" shale actually serve two purposes: (1) as a control for unmineralized, relatively organic carbon-rich Nonesuch Fm.; and (2) as a means to examine effects of thrust-related mineralization without the overprint of earlier main-stage $\mathrm{Cu}$ mineralization.

The third stratigraphic horizon examined in this study is the uppermost Copper Harbor Fm., or in mine terminology, the "lower sandstone" (Fig. 3d). In most mine exposures, the "lower sandstone" is unmineralized and consists of coarse- to fine-grained red sandstone. However, in a few areas the "lower sandstone" contains rich disseminations of native $\mathrm{Cu}$ and is also characterized by chlorite and pyrobitumen (altered petroleum) cements (Fig. 4).

\subsection{Structural geology and chronology}

Recent work has documented that the structural and mineralization history of the White Pine area is more complex than heretofore recognized. The White Pine mine can be divided into three structural domains (Mauk et al., 1989; Fig. 1c). The dominantly extensional northeastern domain contains $\mathrm{N}-\mathrm{S}$-trending high-angle normal faults. The transitional southeastern domain is characterized by NESW-trending high-angle normal and reverse faults, whereas the compressional southwestern domain includes south-dipping, northward-verging thrust faults.

Mauk et al. (1989) conclude the area has been affected by three episodes of faulting and two stages of $\mathrm{Cu}$ mineralization, which they combine into a four-part chronological sequence:

(I) The first structural event in the White Pine area was synsedimentary faulting. Zones of abrupt changes in sedimentary thicknesses and facies, accompanied by increased amounts of soft-sediment deformation, delineate synsedimentary faults which strike both parallel and perpendicular to the inferred margin of the rift. 


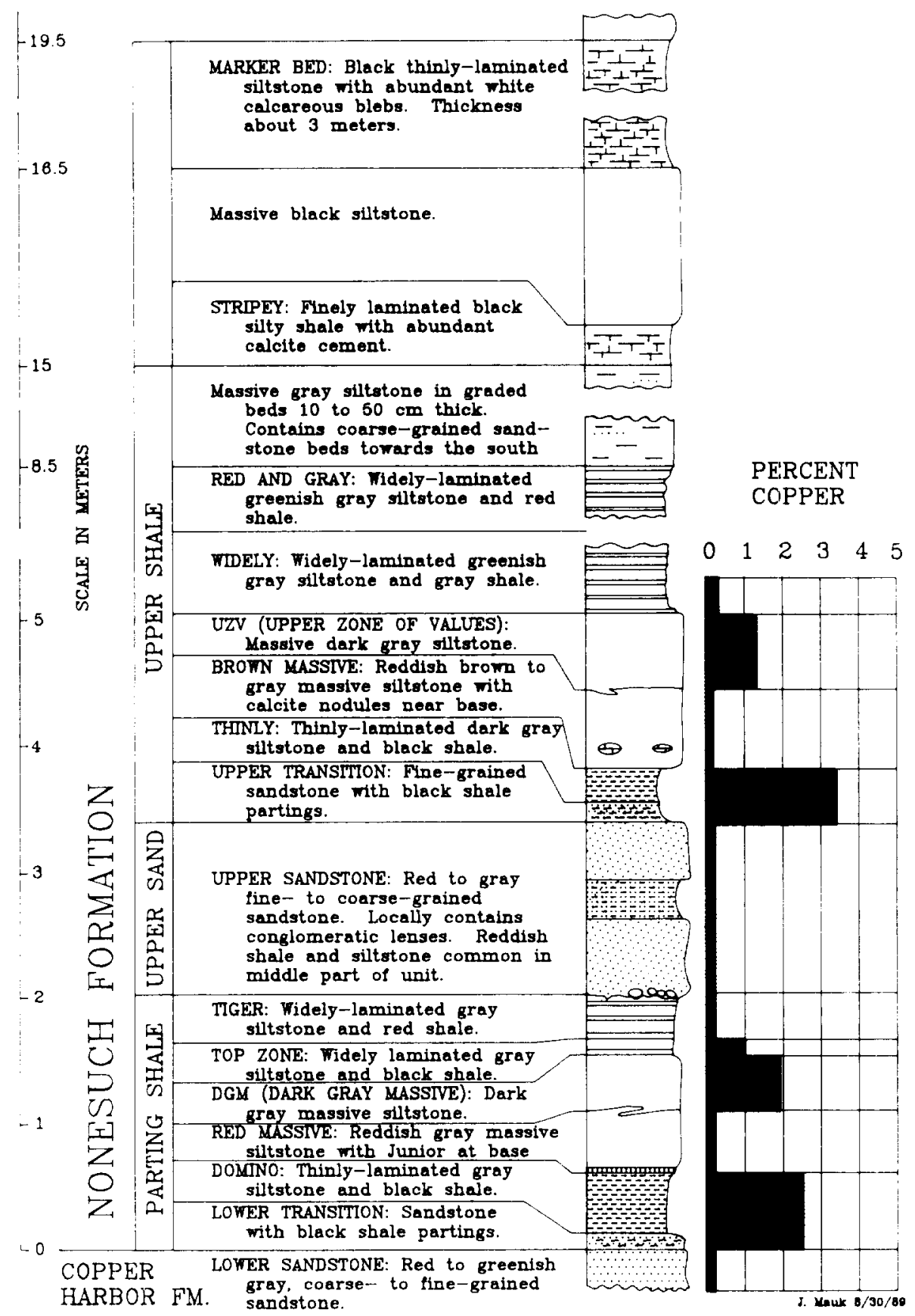

Fig. 2. Generalızed stratigraphy of the lower Nonesuch Fm. at the White Pine mine. Modified from Ensign et al. (1968).

(II) The first phase of $\mathrm{Cu}$ mineralization, referred to as "main-stage" mineralization, is the classic, sediment-hosted stratiform $\mathrm{Cu}$ that formed during early diagenesis (e.g., White and Wright, 1954, 1966; Ensign et al., 1968; Brown,
1971). Brown (1971) and White (1971) postulated that $\mathrm{Cu}$ migrated into basal reduced strata of the Nonesuch Fm. from underlying, highly permeable red beds of the Copper Harbor Conglomerate, which acted as an aquifer 

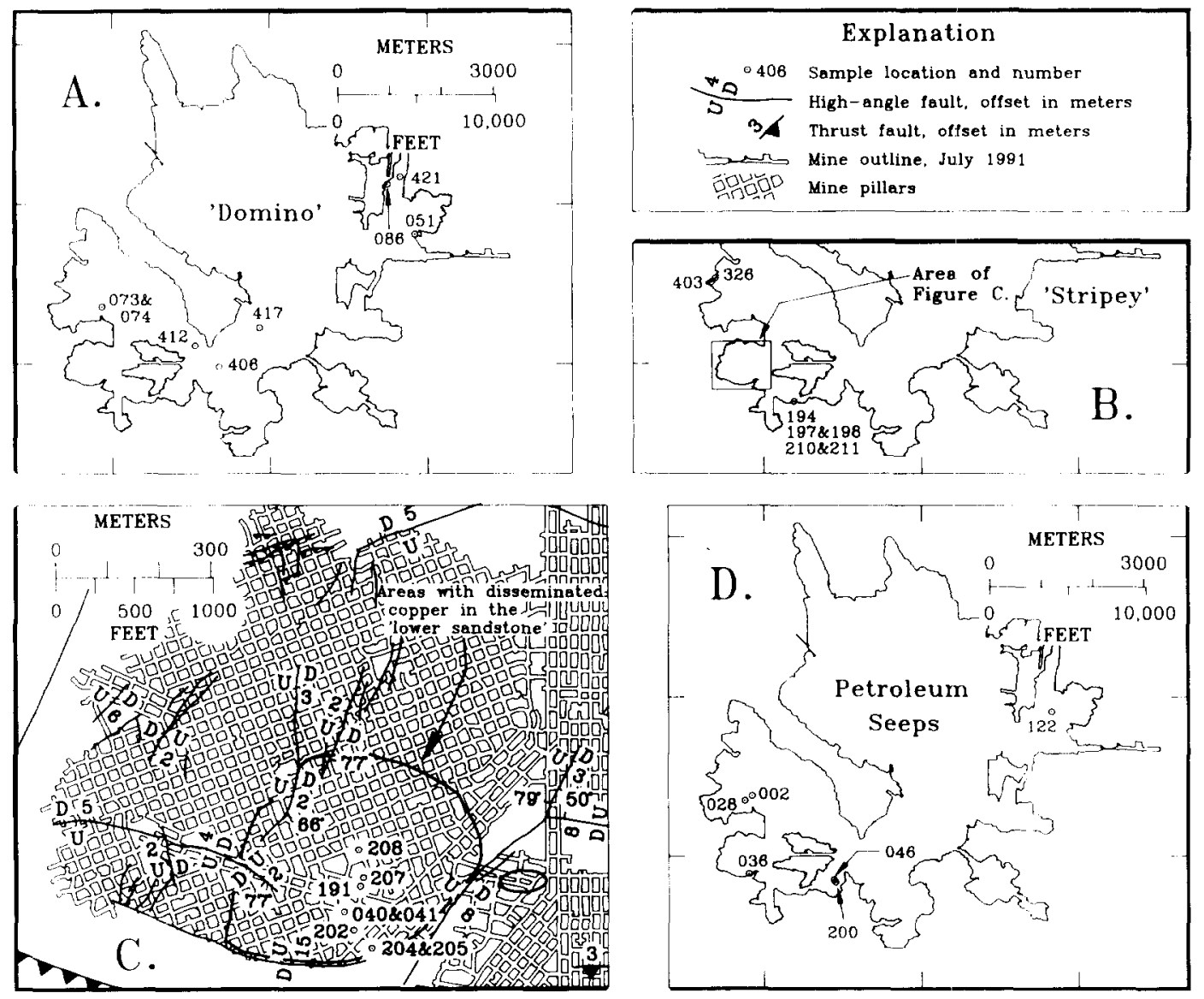

Fig. 3. Location of samples analyzed during this investigation: (A) samples from the "domino" shale; (B) samples from the "stripey" shale; (C) samples from the "lower sandstone"; and (D) petroleum seep samples.

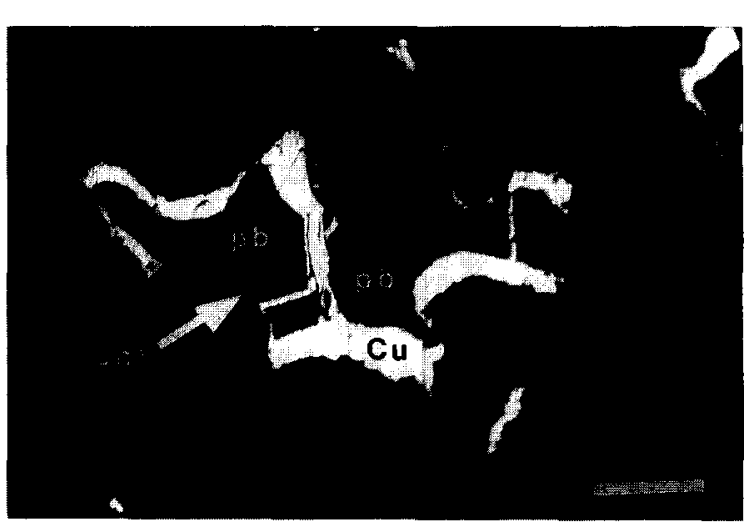

Fig. 4. Reflected light photograph of pore-filling cement in the "lower sandstone". From core to rim: chlorite, native $\mathrm{Cu}$, and pyrobitumen. Sample 040 . Scale bar is 100 $\mu \mathrm{m}$. during fluid migration.

(III) Following main-stage mineralization, high-angle, dominantly normal faults cut the mine area offsetting, but otherwise not affecting the main-stage mineralization.

(IV) In the southwestern domain of the mine (cf. Fig. 1c), major thrust faults with throws of up to $80 \mathrm{~m}$ dominate the structural style, and high-angle faults were locally reactivated as tear faults (Fig. 1b). A second stage of $\mathrm{Cu}$ mineralization accompanied thrusting, post-dating and increasing the grade of mainstage ore (Mauk et al., 1989). Compression during the thrusting event may have locally bent high-angle faults in the southeastern domain. 


\subsection{Thermal constraints}

Former workers have cited several lines of evidence to constrain paleotemperatures at White Pine. Brown (1971) used the existence of a pink bornite which exolves chalcopyrite when annealed at temperatures greater than $75^{\circ} \mathrm{C}$ to infer temperatures of $<75^{\circ} \mathrm{C}$. He also noted that the presence of djurleite $\left(\mathrm{Cu}_{1.96} \mathrm{~S}\right)$ indicated a maximum temperature of $93^{\circ} \mathrm{C}$ because djurleite breaks down to chalcocite and digenite above that temperature. However, given the rapid re-equilibration rates of many $\mathrm{Cu}$-Fe-sulfides (Barton and Skinner, 1979), these $\mathrm{Cu}-\mathrm{Fe}$-sulfide thermometers appear tenuous. Meinschein et al. (1964) cited abundant porphyrins in the lower Nonesuch Fm. at White Pine, and claimed this limited temperatures to $<120-175^{\circ} \mathrm{C}$, depending on duration of heating. Nishioka ( 1983 ) used fluid inclusion homogenization temperatures from vein calcite, coupled with estimates of paleodepth of the Nonesuch Fm. to constrain veinfilling temperatures to the range $70-100^{\circ} \mathrm{C}$. Unfortunately, we cannot distinguish whether veins she studied formed during early extensional faulting or subsequent thrusting, and therefore this temperature range does not necessarily reflect temperatures during main- or second-stage mineralization. Nishioka (1983) also observed monoclinic chalcocite in some veins; this restricts temperatures of formation of these veins to $<103^{\circ} \mathrm{C}$. However, we have not been able to discern whether the veins containing this type of chalcocite formed during the episode of high-angle, dominantly normal faulting, or during thrusting and second-stage mineralization. In spite of the above uncertainties, coincidence of these various thermal indices, combined with lack of evidence for substantially higher temperatures, suggests that $100^{\circ} \mathrm{C}$ is a reasonable estimate of maximum temperature at White Pine.

\section{Methods}

Most samples examined in this study were collected from freshly blasted mine faces in order to minimize anthropogenic contamination. When sampling in older portions of the mine, extreme care was taken to select sites with no obvious contamination. Coarsely crushed samples were split for organic and inorganic analyses. Powdered whole-rock samples were combusted in a Leco ${ }^{\circledR} 320 \mathrm{C} / \mathrm{S}$ instrument for analysis of total carbon and sulfur contents. Content of organic carbon was determined by reaction of whole-rock powder with $1 N \mathrm{HCl}$ overnight. After decanting the solution, the sample was treated with hot $1 \mathrm{~N} \mathrm{HCl}$ to remove refractory carbonate phases. Residual solids were collected on glass fiber filters, neutralized with distilled water, dried and combusted. $\mathrm{Cu}$ assays were determined by electrolysis in the analytical laboratory at the Copper Range Company, White Pine, Michigan, U.S.A.

Samples of powdered rock were extracted in a Soxhlet apparatus (48-60 hr) using dichloromethane as a solvent. Soluble organic matter (bitumen) was concentrated using a Bucchi ${ }^{\circledR}$ rotovapor and brought to a volume of $10 \mathrm{ml}$. An aliquot of bitumen was transferred to a glass vial, dried at room temperature under a stream of $\mathrm{N}_{2}$ gas, and weighed to determine yield. A second aliquot of bitumen was deasphaltened in cold hexane and then separated into saturated hydrocarbons, aromatic hydrocarbons and polar compounds (N-, S- and O-bearing compounds) on a column (13-mm diameter $X$ $50-\mathrm{mm}$ length) of silica gel (activated at $200^{\circ} \mathrm{C}$ ) by sequential elution with hexane, benzene and benzene-methanol $(1: 1)$. Seep oil samples were collected by Soxhlet extraction of oil-stained rock chips and fractionated following the above procedure.

Gas chromatography of the saturated hydrocarbon fraction was carried out on a Hewlett Packard ${ }^{\circledR}$ 5890A using a fused silica capillary column ( $\mathrm{HP}^{\circledR}$ Ultra $25 \mathrm{~m} \times 0.32-\mathrm{mm}$ i.d. $\times$ 
$0.52-\mu \mathrm{m}$ film thickness) and a splitless injector $\left(325^{\circ} \mathrm{C}\right)$. The oven of the gas chromatograph was programmed from $50^{\circ}$ to $130^{\circ} \mathrm{C}$ at $10^{\circ} \mathrm{C} \mathrm{min}{ }^{-1}$, from $130^{\circ}$ to $295^{\circ} \mathrm{C}$ at $4^{\circ} \mathrm{C}$ $\min ^{-1}$, and held at $295^{\circ}$ for $15 \mathrm{~min}$. The gas chromatograph was fitted with a flame ionization detector for hydrocarbons and a flame photometric detector for S-bearing organic compounds. Column flow was split in a $1: 1$ ratio just prior to entering the detectors. Isotopic compositions of individual $n$-alkanes in the saturated hydrocarbon fraction were measured using gas chromatography-combustionmass spectrometry as described by Freeman et al. (1990).

Field and standard petrographic observations including transmitted white light, reflected white light and reflected ultraviolet (UV) epifluorescence microscopy were used to establish paragenetic relations.

\section{Results}

\subsection{Fault-associated petroleum occurrences}

In the mine area, field and petrographic studies have established six types of petroleum occurrence: (1) liquid inclusions of petroleum in veins filling or adjacent to thrust and tear faults; (2) droplet-shaped inclusions of solid pyrobitumen (altered petroleum) in veins spatially associated with thrust and tear faults; (3) subparallel trains of liquid petroleum inclusions in microfractures genetically related to microthrusts; (4) solid pyrobitumen cement in the "lower sandstone"; (5) pore-filling petroleum in the "lower sandstone"; and (6) active oil seeps.

Petrographic examination reveals two types of inclusions with organic matter in calcite and barite that fill veins associated with thrust and tear faults. Type- 1 inclusions are $1-10 \mu \mathrm{m}$ in diameter and are filled with petroleum (Fig. $5 \mathrm{a}$ and $\mathrm{b}$ ). Petroleum in type- 1 inclusions contains aromatic compounds that can be detected with UV microscopy. Many type- $l$ in- clusions are two-phase, consisting of a liquid phase filling $80-95 \%$ of the inclusion and a vapor bubble filling the remaining portion. Vapor bubbles in some inclusions move continuously, demonstrating that the surrounding inclusion contents are liquid. Virtually all type1 fluid inclusions are secondary or pseudosecondary, though a small fraction may be primary. Type-2 inclusions are 50-100 $\mu \mathrm{m}$, mushroom-shaped pyrobitumen inclusions (Fig. 5c). Flattened portions of these droplets are aligned on growth planes of barite and sparry calcite crystals, indicating growth as primary fluid inclusions, as first noted by Kelly and Nishioka (1985).

A third type of petroleum-filled inclusion exists in subparallel trains along microfractures in the "lower sandstone" (type 3 ). Type3 inclusions most commonly fill fractured quartz grains (Fig. 5d), but they also occur in calcite cement (Fig. 5e). Like type- 1 inclusions, petroleum in type- 3 inclusions fluoresces under UV microscopy because of associated aromatic compounds, so this technique was used to evaluate their distribution. In the southwestern domain, $31 \%$ of the samples contain petroleum fluid inclusions $(n=70)$, compared with $8 \%$ in the southeastern domain $(n=12)$ and $21 \%$ in the northeastern domain $(n=19)$.

Pyrobitumen is one of the pore-filling cements in the "lower sandstone" in areas where the sandstone contains native $\mathrm{Cu}$. The typical pore-filling sequence, from rim to core, is chlorite, native $\mathrm{Cu}$ and pyrobitumen (type 4; Fig. 4 ). This type of copper/pyrobitumen occurrence is restricted to the southwestern domain and the northeastern domain adjacent to the White Pine fault.

\subsection{Seep petroleum and petroleum in the "lower sandstone"}

Active petroleum seeps (type 6) occur throughout the mine, irrespective of local tectonic fabric. Seeps occur as 1-5-m-wide oozes of petroleum emanating from faults, joints and 

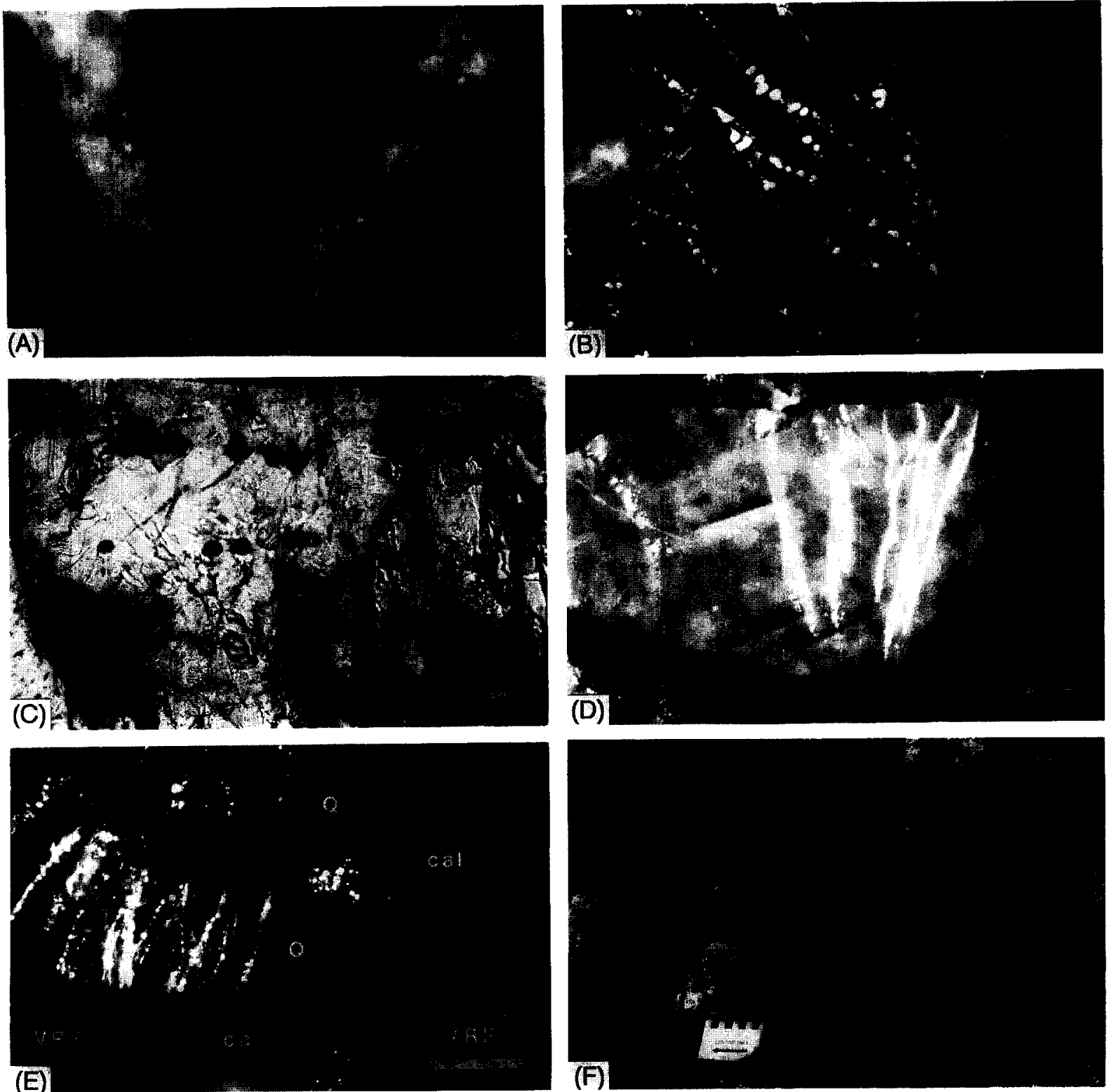

Fig. 5. Petroleum occurrences at White Pine. Scale bar in all petrographic photos is $100 \mu \mathrm{m}$.

A. UV photograph of abundant fluorescent inclusions in vein-filling barite laths in sample 188 .

B. UV photograph of abundant fluorescent inclusions in vein-filling sparry calcite in sample 188 .

C. Mushroom-shaped pyrobitumen inclusions, photographed under transmitted light, showing flattened portions of droplets aligned on growth planes of sparry calcite. Sample 099.

D. UV photograph of subparallel trains of petroleum inclusions in a quartz grain. Inclusions occur along Riedel shears associated with a microthrust in the "lower sandstone". Sample 099.

E. UV photograph of subparallel trains of petroleum inclusions in quartz grains and calcite cement along Riedel shears associated with a microthrust in the "lower sandstone". Sample 092.

F. Oil seep in the southwestern domain of the mine. Scale in $\mathrm{cm}$. 
roof bolt holes within the mine (Fig. 5f). We have not observed any bedding-plane parallel seep sources; all seeps emerge from the back (roof) of the mine, suggesting that source or reservoir strata lie above the ore horizon. Petroleum also occurs locally in pores of the "lower sandstone" (type 5), spatially associated with pyrobitumen cements.

Gas chromatograms of the saturated hydrocarbon fraction of seep petroleums show wide distributions of $n$-alkanes and monomethyl alkanes (centrally and terminally branched; Fig. $6 a$ and $b$ ). Pristane and phytane occur in rela- tively low concentrations. Organosulfur compounds were not detected in the saturated and aromatic hydrocarbon fractions. Seeps from the northeastern domain of the mine have higher relative peak areas of $n$-alkanes from $\mathrm{C}_{20}$ to $C_{30}$ than seep petroleums from the southwestern domain.

Petroleum-stained samples from the "lower sandstone" contain relatively high concentrations of soluble organic matter. Extraction yields vary from 225 to $2223 \mathrm{ppm}$ extract relative to rock, which is $>10 \%$ of the total organic carbon. Gas chromatograms of the satu-
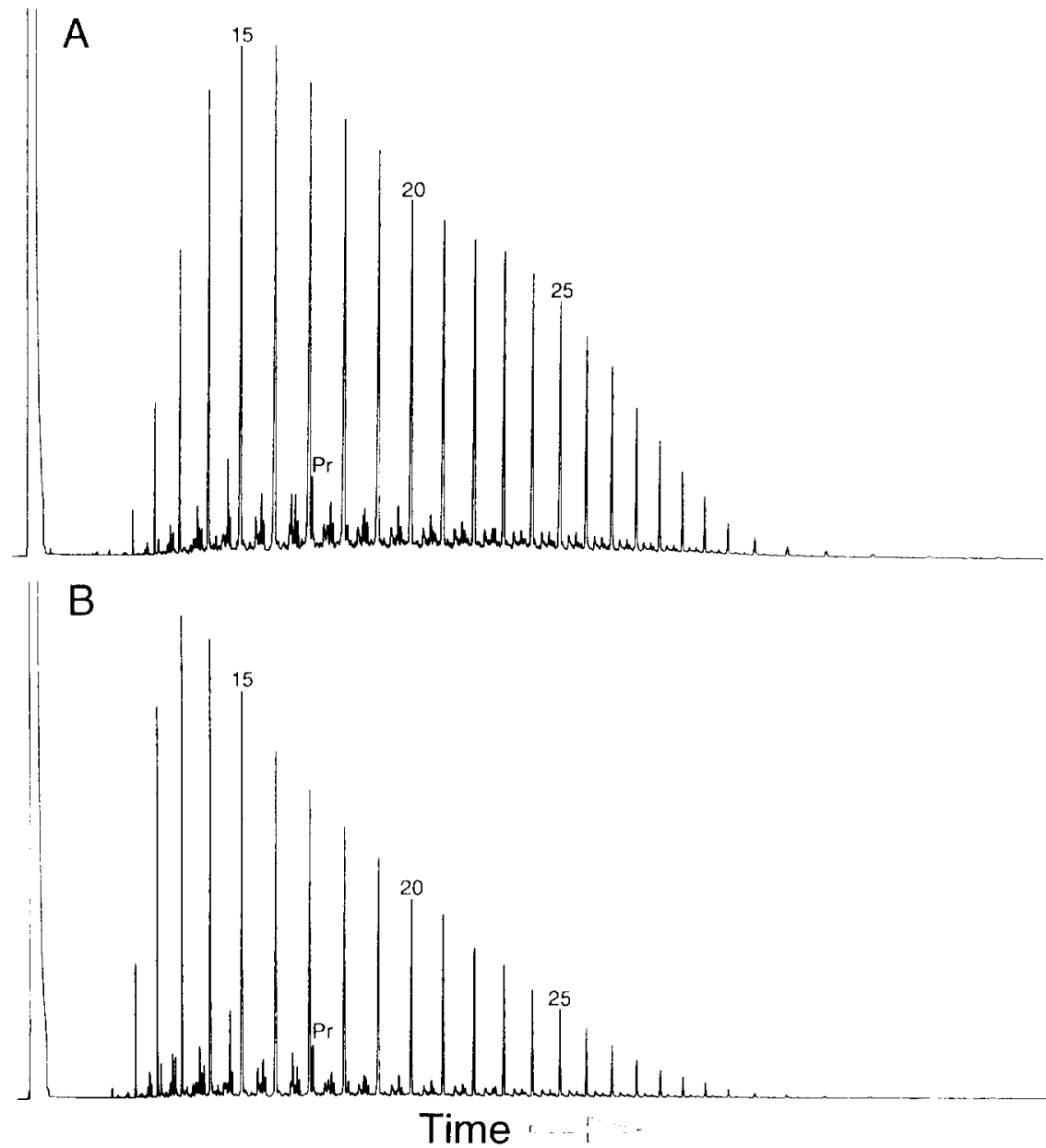

Fig. 6. A. Gas chromatograms of the saturated hydrocarbon fraction of seep petroleum from the northeastern domain. Sample 091.

B. Gas chromatograms of the saturated hydrocarbon fraction of seep petroleum from the southwestern domain. Sample 028 . 


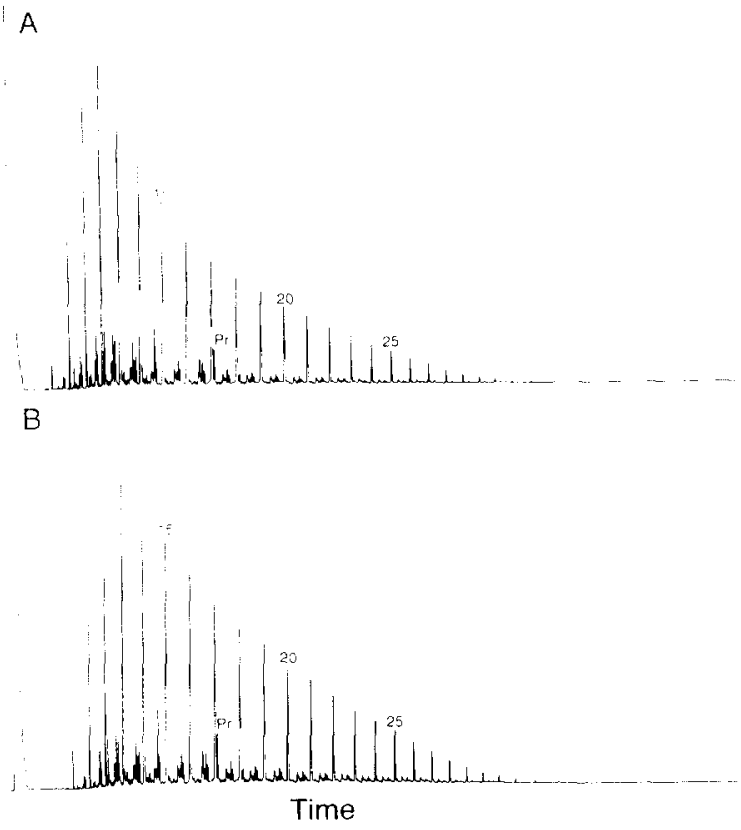

Fig. 7. Gas chromatograms of the saturated hydrocarbon fraction of petroleum from the "lower sandstone": (A) sample 040 ; and (B) sample 191.

rated hydrocarbon fraction show homologous series of $n$-alkanes and monomethyl alkanes (Fig. 7). Pristane and phytane occur in relatively low concentrations. Low-molecularweight components $\left(\mathrm{C}_{10}-\mathrm{C}_{15}\right)$ are predominant; $n$-alkane distributions display a pronounced concave-up envelope.

\subsection{Bitumen in the "domino" and "stripey" shales}

Within the mine, the "domino" and "stripey" shales contain low concentrations of indigenous extractable organic matter (bitumen). Extraction yields of samples from the "stripey" shale range from 58 to $192 \mathrm{ppm}$ and average $115 \mathrm{ppm}$, which is $\sim 3 \%$ of total organic carbon $\left(\mathrm{C}_{\text {org }}\right)$. Yields from the "domino" shale are substantially lower, ranging from 10 to $70 \mathrm{ppm}$ extract relative to rock, and averaging $30 \mathrm{ppm}$, which is $\sim 0.6 \%$ of $\mathrm{C}_{\text {org. }}$. Gas chromatograms of the saturated hydrocarbon

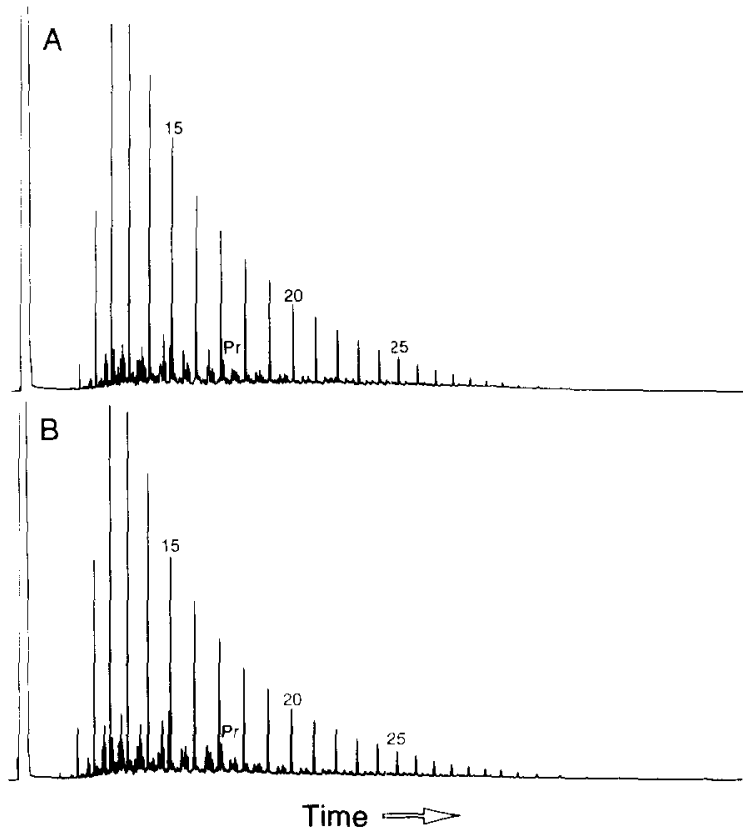

Fig. 8. Gas chromatograms of the saturated hydrocarbon fraction of bitumen from the "stripey" shale: (A) sample 326 , which is pyritic; and (B) sample 194, which contains chalcocite.

fraction of bitumen extracted from both chalcocitic and unmineralized samples of the "stripey" shale contain monomethyl alkanes and a homologous series of $n$-alkanes with a predominance of the lower-molecular-weight homologues in a concave-up distribution (Fig. 8). Pristane $/ n-\mathrm{C}_{17}$ and phytane $/ n-\mathrm{C}_{18}$ ratios are low. Gas chromatograms of the saturated hydrocarbon fraction of bitumen extracted from the "domino" shale generally show low concentrations of $n$-alkanes and relatively high concentrations of unresolved components in the saturated hydrocarbon fraction (Fig. 9a). Pristane $/ n-\mathrm{C}_{17}$ and phytane $/ n-\mathrm{C}_{18}$ ratios are higher than those from seep and pore-filling petroleums (petroleum types 5 and 6) and those from extracts of the "stripey" shale. Homologous series of monomethyl alkanes are recognized in some samples from the "domino" shale.

Similar to bitumens from White Pine, indigenous bitumens in unmineralized Nonesuch Fm. strata from Michigan contain $n$-alkanes, 


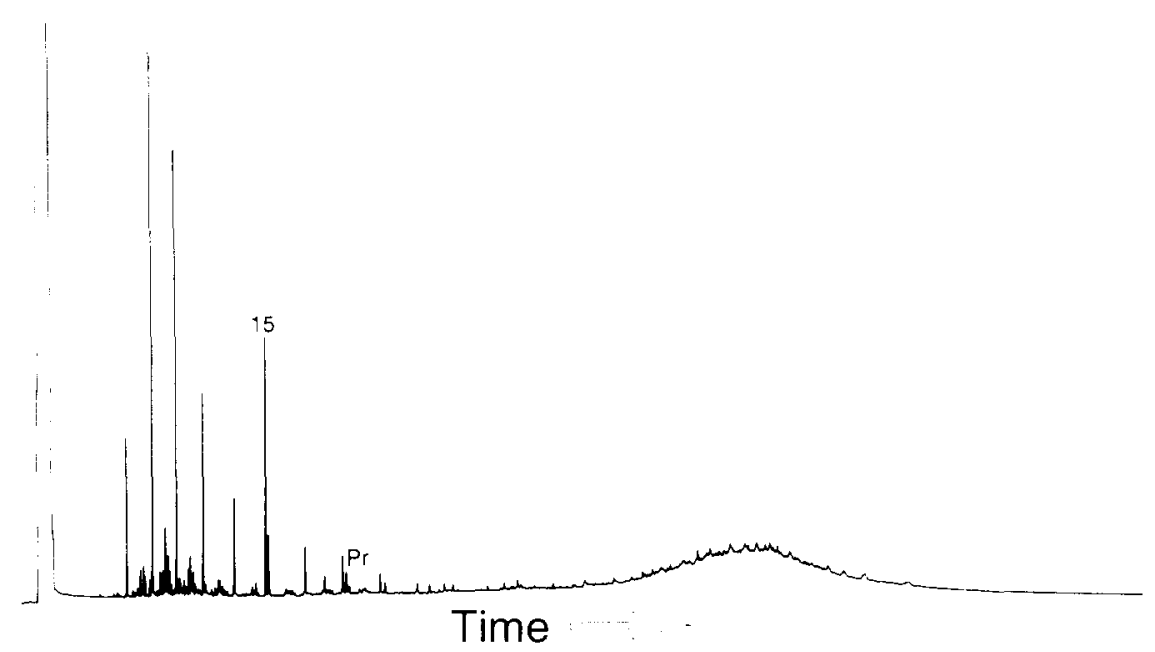

Fig. 9. Gas chromatogram of the saturated hydrocarbon fraction of bitumen from the "domino" shale. Sample 412.

monomethyl alkanes and acyclic isoprenoids (Hieshima and Pratt, 1991), but have higher proportions of isoprenoid and monomethyl alkanes and different distributions of $n$-alkanes (Fig. 10). Extraction yields of unmineralized Nonesuch Fm. strata from Michigan range from 39 to $341 \mathrm{ppm}$ extract relative to rock, and average $163 \mathrm{ppm}$, which is $\sim 1.4 \%$ of $\mathrm{C}_{\mathrm{org}}$ (Hieshima and Pratt, 1991).

\subsection{Isotopic compositions of individual $n$ - alkanes}

Isotopic compositions of individual $n$-alkanes from $C_{15}$ to $C_{25}$ follow similar patterns of ${ }^{13} \mathrm{C}$ depletion in most samples of petroleum and bitumen (Fig. 11). $\mathrm{C}_{19}$ is not depicted in the isotopic profiles of some samples because partial elution with an unknown component prevented determination of its isotopic composition. Most of the $n$-alkanes fall within the $\delta^{13} \mathrm{C}$ range from -33 to $-30 \%$ vs. $\mathrm{PDB}$, slightly enriched in ${ }^{13} \mathrm{C}$ relative to the isotopic composition of total organic carbon in unmineralized upper Nonesuch Fm. strata $\left(\delta^{13} \mathrm{C}\right.$ -33.9 to $-33.4 \%$, average $-33.6 \%$; Hieshima et al., 1990). In general, the $C_{15}-C_{18} n$-alkanes are depleted in ${ }^{13} \mathrm{C}$ by $0.2-1 \%$ relative to those in the range $\mathrm{C}_{20}-\mathrm{C}_{25}$. The $n$-alkanes from chalcocite-bearing samples of the "stripey" shale, bitumen from unmineralized strata and seep petroleum display this pattern most clearly.

\subsection{Copper-sulfur-organic carbon}

Contents of $\mathrm{Cu}$, total sulfur $\left(\mathrm{S}_{\mathrm{tot}}\right)$ and total organic carbon $\left(\mathrm{C}_{\text {org }}\right)$ display considerable stratigraphic variation in the lower Nonesuch Fm. at White Pine (Table 1). The "lower sandstone" contains the highest concentrations of $\mathrm{C}_{\mathrm{org}}$. Organic carbon in these samples occurs dominantly as pyrobitumen, with subsidiary petroleum. $\mathrm{Cu}$ contents vary from $0.03 \%$ to $11.24 \%$. Low sulfur contents, averaging $0.01 \%$, are consistent with petrographic data revealing that native $\mathrm{Cu}$ is the dominant metal-bearing species. Samples from the "domino" and "stripey" shales contain less organic carbon, averaging $0.42 \%$ and $0.34 \%$, respectively. Cu contents of the "domino" shale are uniformly high and typical of economic concentrations; chalcocite is the only sulfide. The "stripey" shale contains $0.03-9.5 \% \mathrm{Cu}$; higher values reflect local addition of chalcocite in samples adjacent to tear and thrust faults. Sulfur contents of the "domino" and 


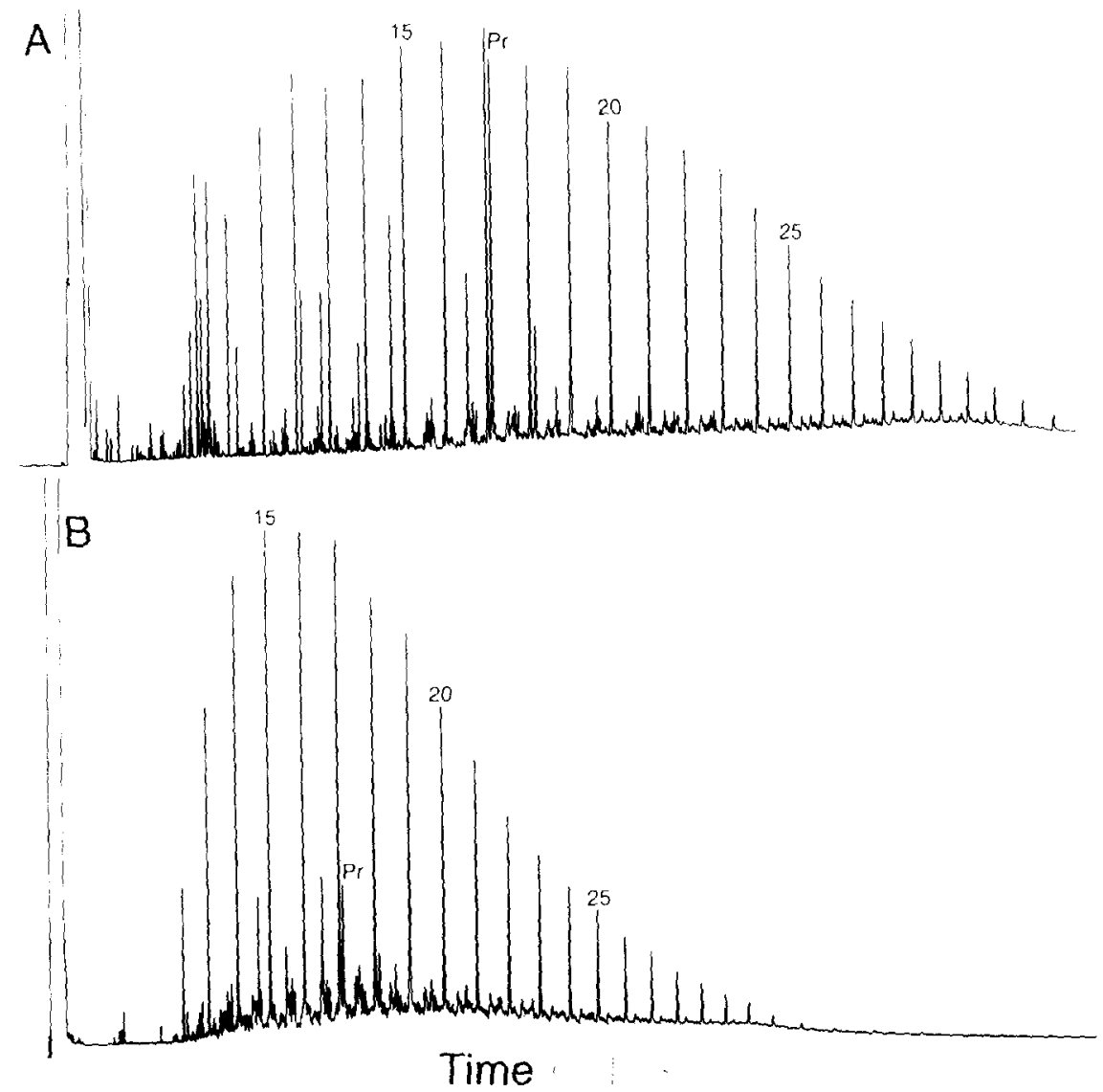

Fig. 10. Gas chromatograms of the saturated hydrocarbon fraction of bitumen from black shales in the upper Nonesuch Fm. outside the mine area: (A) Michigan sample NSS 887-3I; and (B) Wisconsin sample NSS 589-54. (From Hieshima and Pratt, 1991.)

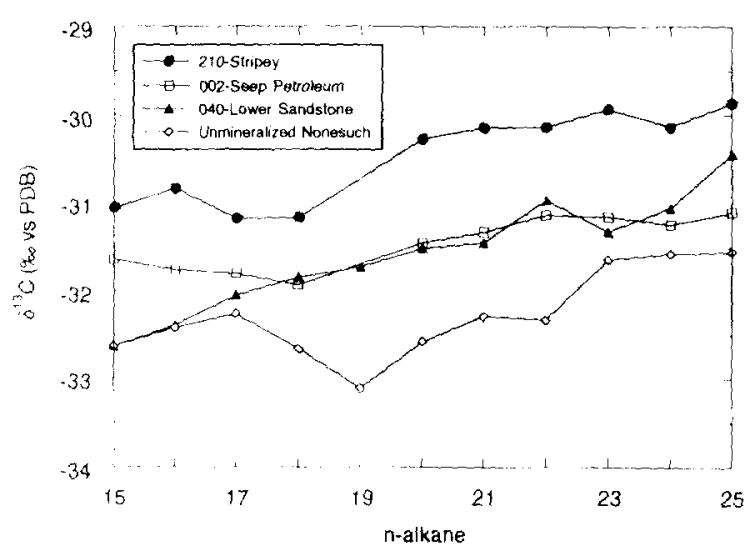

Fig. 11. Isotopic compositions of individual $n$-alkanes from $C_{15}$ to $C_{25}$. "stripey" shales are variable, in the ranges $0.08-1.58 \%$ and $0.59-2.68 \%$, respectively.

\section{Discussion}

\subsection{Petroleum fluid inclusions, pyrobitumen} inclusions and pyrobitumen cements

Type- $1,-2$ and -3 inclusions, and pyrobitumen cements in the "lower sandstone", are spatially associated with compressional faults, suggesting that petroleum migrated into the White Pine region along fault-related conduits synchronously with thrusting and second-stage mineralization. The unexpectedly high per- 
TABLE 1

Whole-rock analyses of selected strata from the lower Nonesuch Formation

\begin{tabular}{|c|c|c|c|c|c|c|}
\hline Stratum & $\begin{array}{l}\text { Sample } \\
\text { No. }\end{array}$ & $\begin{array}{l}S \\
(w t \%)\end{array}$ & $\begin{array}{l}\mathrm{C}_{\text {org }} \\
(w t \%)\end{array}$ & $\begin{array}{l}\mathrm{Cu} \\
(\mathrm{wt} \%)\end{array}$ & $\begin{array}{l}\mathrm{C}_{\text {tot }} \\
(\mathrm{wt} \%)\end{array}$ & $\begin{array}{l}\text { Extraction yield } \\
\text { (ppm) }\end{array}$ \\
\hline "Stripey" & 194 & 2.68 & 0.44 & 9.50 & 1.12 & 57.53 \\
\hline "Stripey" & 198 & 1.52 & 0.44 & 1.83 & 3.30 & 116.28 \\
\hline "Stripey" & 210 & 1.37 & 0.44 & 0.41 & 3.51 & 93.17 \\
\hline "Stripey" & 211 & 0.99 & 0.36 & 0.39 & 0.75 & n.d. \\
\hline "Stripey" & 326 & 0.94 & 0.42 & 0.06 & 1.87 & 191.67 \\
\hline "Stripey" & 403 & 0.59 & 0.44 & 0.03 & 1.43 & 167.60 \\
\hline "Domino" & 051 & 0.08 & 0.19 & 0.74 & 0.87 & n.d. \\
\hline "Domino" & 073 & 1.07 & 0.27 & 6.31 & 0.27 & n.d. \\
\hline "Domino" & 074 & 1.24 & 0.38 & 6.82 & 0.50 & 9.67 \\
\hline "Domino" & 086 & 0.03 & 0.32 & 0.76 & 0.48 & 18.66 \\
\hline "Domino" & 406 & 1.25 & 0.37 & 7.89 & 0.42 & n.d. \\
\hline "Domino" & 412 & 1.58 & 0.53 & 6.58 & 0.44 & 70.55 \\
\hline "Domino" & 417 & 0.54 & 0.34 & 5.35 & 0.20 & 12.26 \\
\hline "Lower standstone" & 040 & 0.02 & 1.93 & 11.24 & 3.04 & $2,223.11$ \\
\hline "Lower standstone" & 041 & 0.01 & 0.11 & 0.07 & 0.50 & n.d. \\
\hline "Lower standstone" & 202 & 0.01 & 0.70 & 2.27 & 1.17 & n.d. \\
\hline "Lower standstone" & 204 & 0.01 & 0.62 & 2.76 & 0.96 & 843.90 \\
\hline "Lower standstone" & 205 & 0.02 & 0.24 & 0.03 & 0.55 & n.d. \\
\hline "Lower standstone" & 207 & 0.02 & 0.87 & 2.57 & 0.98 & n.d. \\
\hline "Lower standstone" & 208 & 0.01 & 0.91 & 3.48 & 1.13 & n.d. \\
\hline
\end{tabular}

n.d. = not determined.

centage $(21 \%)$ of samples containing fault-associated petroleum inclusions in the northeastern domain arises from two atypical samples collected from rare thrust faults with offsets of $0.2-1 \mathrm{~m}$; two other samples contain petroleum inclusions along microfractures not recognized in the field. Therefore, petroleum inclusions are more common proximal to major tear and thrust faults in the southwestern domain $(31 \%)$ than in the less deformed southeastern $(8 \%)$ and northeastern $(21 \%)$ domains, although compressional faults in any domain may contain hydrocarbon-bearing fluid inclusions. Vein-filling calcite associated with mushroom-shaped pyrobitumen inclusions ( type 2) yielded a model age of $1047 \pm 35$ Ma (Rb-Sr; Ruiz et al., 1984), leading Kelly and Nishioka (1985) to conclude that primary inclusions of pyrobitumen (type 2 ) were formed by petroleum migrating at that time.

Kelly and Nishioka (1985) interpreted the following sequence of diagenesis, migration of petroleum and mineralization in the "lower sandstone": (1) chlorite formed; (2) petroleum migrated into the remaining pore space; (3) alteration of petroleum formed pyrobitumen, which shrank and cracked; and (4) native $\mathrm{Cu}$ precipitated in voids, filled cracks, veined and replaced pyrobitumen (cf. Fig. 4). We recognize another possible sequence: petroleum and cupriferous fluids entered the "lower sandstone" more-or-less synchronously, though possibly along different flow paths, and oxidation of petroleum along with concomitant reduction of $\mathrm{Cu}^{+}$to $\mathrm{Cu}^{0}$ formed pyrobitumen and native $\mathrm{Cu}$. In this hypothesis, apparent veining of pyrobitumen by $\mathrm{Cu}$ would reflect growth of native $\mathrm{Cu}$ into liquid petroleum from nucleation sites on chlorite-lined rims of pores.

Nishioka (1983) presented $\delta^{13} \mathrm{C}$ data from vein calcite; most values clustered around -8 to $-6 \%$, suggesting some incorporation of organic $\mathrm{C}$. 


\subsection{Maturation and migration of fault- associated petroleums}

Although field and petrographic data lead us to infer that type- $1,-2$ and -3 inclusions and pyrobitumen cement are spatially and temporally related to compressional faulting, it is more difficult to deduce the source and maturation histories of these petroleums. Fault-associated petroleums presumably represent maturation of Nonesuch Fm. organic matter, because at the time of thrusting, the Nonesuch Fm. contained the only known source rocks in the basin. However, organic matter from the White Pine region may not have been the source of this petroleum. Maturation of petroleum is a function of several parameters including abundance and type (reactivity) of kerogen, temperature and time. Kerogen in the lower Nonesuch Fm. may have been oil prone if similar in character to that in unmineralized strata (Hieshima and Pratt, 1991), but only low concentrations of organic carbon occur in the basal part of the section. Available thermometric data suggest that maximum temperatures at White Pine during both mineralization episodes did not exceed $100^{\circ} \mathrm{C}$. Less than 30 Ma probably passed between sedimentation and thrusting, as suggested by overlapping geochronologic data constraining age of sedimentation [ $1044 \pm 45 \mathrm{Ma}$, recalculated from $\mathrm{Rb}-\mathrm{Sr}$, whole-rock data of Chaudhuri and Faure (1967), using model-3 regression on Isoplot (i) (Ludwig, 1990) and decay constants of Steiger and Jäger (1977) ]; the model age of calcite veins at White Pine $(1047 \pm 35 \mathrm{Ma}$; Ruiz et al., 1984); and the age of native $\mathrm{Cu}$ mineralization in the Keweenaw peninsula ( $\mathrm{Rb}-\mathrm{Sr}$, calcite, epidote and microcline, $1060 \pm 20 \mathrm{Ma}$ - Bornhorst et al., 1988; Rb-Sr, chlorite and microcline, $1047 \pm 33 \mathrm{Ma}-$ Bornhorst et al., 1988). Native Cu mineralization in the Keweenaw district was (White, 1968, p.313)

"contemporaneous with or later than much or most of the deformation", and may therefore correlate with second-stage mineralization at White Pine which was contemporaneous with deformation (Mauk et al., 1989). Therefore, three factors inhibit petroleum formation prior to thrusting in Nonesuch Fm. sediments near White Pine: low temperature, low organic matter content and short time.GLIMPCE seismic profiles in Lake Superior show that the Midcontinent Rift fill thickens significantly to the north under the axis of Lake Superior to as much as $36 \mathrm{~km}$, including up to $10 \mathrm{~km}$ of sediment (Behrendt et al., 1988; Dickas, 1988; Cannon et al., 1989; Dickas and Mudrey, 1989; McGinnis, 1990). At the time of thrusting, the Nonesuch Fm. in the rift axis was probably capped by $4-6 \mathrm{~km}$ of sediment (W.F. Cannon, pers. commun., 1991). We can estimate the temperature of the Nonesuch Fm. in the rift axis using the heat conduction equation for one-dimensional heat transfer. This equation is:

$T_{z}=T_{0}+(q / k) z$

where $q$ is heat flow; $k$ is thermal conductivity; $z$ is depth; and $T_{0}$ is the surface temperature. Given estimates of paleo-heat flow in the rift basin and thermal conductivities for the Freda, Jacobsville and Nonesuch Formations, approximate temperatures for the Nonesuch Fm. can be obtained.

Measured heat flow in rifts with significant volcanic rocks is between 80 and $120 \mathrm{~mW} \mathrm{~m}^{-2}$ (e.g., Morgan, 1982; Clarkson and Reiter, 1984; Decker et al., 1984), and we adopt this range for our calculations. The thermal conductivities of the Freda and Jacobsville Sandstones are $2.8 \mathrm{~W} \mathrm{~m}^{-1} \mathrm{~K}^{-1}$ (Birch, 1954) and the thermal conductivity of the Nonesuch Fm. is $2.2 \mathrm{~W} \mathrm{~m}^{-1} \mathrm{~K}^{-1}$ (Roy, 1963).

These heat flow estimates and thermal conductivity measurements allow us to calculate temperatures of the Nonesuch Fm. along the rift axis. If the overlying sediments were $4 \mathrm{~km}$ thick, then the temperature of the Nonesuch 
Fm. was between $140^{\circ}$ and $150^{\circ} \mathrm{C}$. If overlying sediments were $6 \mathrm{~km}$ thick, then the temperature of the Nonesuch Fm. was between $280^{\circ}$ and $300^{\circ} \mathrm{C}$. Although poorly constrained, these estimates indicate that burial temperatures in the axis of the rift were higher than at White Pine. In addition, equivalent fine-grained sediments in sub-basins near the rift axis may contain greater concentrations of organic matter than does the Nonesuch Fm. at White Pine. If these estimates are correct, then temperatures experienced by the Nonesuch Fm. under the thicker, hotter axial portion of the rift (Fig. 1a), were certainly high enough for petroleum maturation in a relatively short period of time.

An alternative to burial maturation of petroleum in the axis of the rift involves maturation by hydrothermal fluids circulating through rift sediments. In modern ocean rift environments, organic matter is locally converted almost "instantaneously" to petroleum (e.g., Simoneit, 1990; Peter et al., 1991). During diagenetic release of fluids from rift sediments, hydrothermal cells may have been established in the rift that locally could have elevated the temperature of the Nonesuch Fm., and thereby expedited conversion of its dispersed organic matter to petroleum.

Spatial association of petroleum with compressional faults strongly suggests that this petroleum, whether generated by heat during normal burial or by hydrothermal circulation, migrated into the White Pine region synchronously with thrusting, using thrust and tear faults as conduits. Porous sandstones adjacent to these structures may have filled with petroleum that subsequently altered to pyrobitumen in the uppermost Copper Harbor Conglomerate.

\subsection{Source and maturation of seep petroleum and petroleum in the "lower sandstone"}

Two factors lead us to propose that organic matter in the Nonesuch Fm. is the source of seep petroleum and petroleum in the "lower sandstone":

(1) Pratt et al. (1991) measured biomarker compositions of bitumen and kerogen pyrolysates of unmineralized Nonesuch Fm. strata and seep petroleum from White Pine, and concluded that these materials were derived from organic matter deposited in the Nonesuch Fm.

(2) The isotopic compositions of individual $n$-alkanes from seep petroleum and petroleum in the "lower sandstone" fall within the range of isotopic compositions determined for bitumen derived from the "stripey" shale and unmineralized Nonesuch Fm. strata (Fig. 11).

Biomarker compositions in the saturated hydrocarbon fraction of two seep petroleums from this study (002 and 046) were measured using multiple-reaction-monitoring gas chromatography-mass spectrometry (MRMGCMS) by R.E. Summons (Bureau of Mineral Resources, Canberra, Australia ). Steranes were not present in detectable concentrations and hopanes were detected in low concentrations in only one seep petroleum sample (046).

Thermal maturity of seep petroleum and petroleum from the "lower sandstone" is interpreted to be higher than that of bitumen from unmineralized Nonesuch Fm. strata, based on the biomarker evidence presented for seep petroleums by Pratt et al. (1991), and the distribution of $n$-alkanes and ratios of pristane $/ n$ $\mathrm{C}_{17}$ and phytane $/ n-\mathrm{C}_{18}$. In general, seeps from the northeastern, unthrusted domain of the mine have a lower inferred thermal maturity than seeps from the thrusted southwestern domain, as reflected by the distribution of $n$-alkanes (Fig. 6). The correlation between inferred maturity and structural complexity suggests that hydrothermal activity associated with second-stage mineralization locally enhanced thermal maturity of seep petroleums in the vicinity of compressional faults. Although the distribution of $n$-alkanes can also be influenced by migration and biodegradation, these factors probably were not significant for White Pine petroleums because seep petroleums from 
the southwestern and northeastern domains probably share similar migration histories and the wide distributions and high concentrations of $n$-alkanes preclude significant biodegradation. Steranes or hopanes would be useful in the assessment of thermal maturity of seep petroleums, yet our failure to detect them during this study forces us to rely on $n$-alkane distributions. Future studies may benefit from analysis of aromatic compounds, such as the methylphananthrenes, that have been demonstrated to have value in the assessment of thermal maturity (e.g., Radke and Welte, 1983; Boreham et al., 1988 ).

The mobility of seep petroleum makes it difficult to place the origin and migration of seep petroleum in the chronology of events at White Pine. Any model for the origin of seep petroleum must account for the following observations and interpretations:

(1) Active seeps occur in all domains of the mine, irrespective of the local or regional tectonic fabric, suggesting that they post-date all phases of deformation.

(2) The distribution of $n$-alkanes suggests that seeps from the northeastern, unthrusted domain of the mine have a lower thermal maturity than seeps from the thrusted southwestern domain (Fig. 6), suggesting that hydrothermal activity associated with second-stage mineralization locally enhanced maturity of seep petroleums in the vicinity of compressional faults.

(3) Seeps emanate from the back of the mine, indicating that reservoirs or source beds for seep petroleums lie above the ore horizon.

(4) The Nonesuch Fm. is the most likely source for White Pine oil seeps.

(5) The lower Nonesuch Fm. at White Pine has a higher level of thermal maturity than unmineralized Nonesuch Fm. strata.

We suggest two possible scenarios for the origin of seep petroleum. The first scenario proposes introduction of petroleum sourced in other areas of the rift during thrusting; this petroleum was stored in faults and fractures, and was released during subsequent brittle deformation to form seeps. Petroleum stored in the heart of the thrust system of the southwestern domain would have a higher thermal maturity than petroleum stored in the northeastern domain, consistent with the relative amounts of compressional faulting and second-stage mineralization observed in these regions. The second scenario proposes that petroleum generated during maturation of the Nonesuch Fm. shales in the vicinity of White Pine, after the thrusting event, could have mixed with petroleums sourced in other areas of the rift which were introduced into the White Pine area during thrusting. Therefore, the measured thermal maturity of oil seeps at White Pine would depend on the proportions in which its locallysourced and distally-sourced components mix, and on the level of maturation of each component. The low concentrations of organic matter in the Nonesuch Fm. near White Pine suggest that alternative (2) is the least likely of the above hypotheses.

We infer that petroleum in the "lower sandstone" is younger than $\mathrm{Cu}$ mineralization and pyrobitumen formation in the "lower sandstone". Presumably, petroleum in the "lower sandstone" represents migration of seep petroleum into this unit, but the migration pathway and alteration history of this oil are not yet known. Additional data are necessary to evaluate the origin and timing of these petroleums.

\subsection{Bitumen from the "stripey" shale}

Three lines of evidence suggest that bitumen extracted from the "stripey" shale is indigenous: (1) there is no visual evidence of migrated petroleum; (2) yields of extractable organic matter are low; and (3) gas chromatograms of the saturated hydrocarbon fraction of bitumen from the "stripey" shale (Fig. 8 ) are different from those of seep petroleum (Fig. 6). Distributions of $n$-alkanes and low pristane/phytane ratios in bitumen from the "stripey" shale close to thrust faults at 
White Pine indicate significantly higher levels of thermal maturity than bitumen from unmineralized upper Nonesuch Fm. strata (Hieshima and Pratt, 1991). Biomarker content of one sample of the "stripey" shale (210) was analyzed by MRM-GCMS (R.E. Summons, unpublished data, 1991). Concentrations of steranes and pentacyclic triterpanes are low and distributions of these components are similar to those of unmineralized strata (Pratt et al., 1991). The ratio of $\mathrm{C}_{29} \alpha \alpha \alpha$ sterane 20S/ $(20 \mathrm{~S}+20 \mathrm{R})$ is 0.5 , close to the equilibrium value of 0.54 . Although the precision of this value is low because of the low concentrations of these compounds, the inferred level of thermal maturity is higher than that for unmineralized strata.

\subsection{Bitumen from the "domino" shale}

Bitumen yields from the "domino" shale are significantly lower than yields from the "stripey" shale. In contrast with bitumens from the "stripey" shale, gas chromatograms of the saturated hydrocarbon fraction of bitumen from the "domino" shale show strong but variable depletion of $n$-alkanes and relatively high concentrations of unresolved compounds, indicating some form of alteration (Fig. 9). Ho et al. (1990) noted similar alteration of bitumen extracted from the "thinly" shale at White Pine (cf. Fig. 2). Two processes could have produced this depletion of $n$-alkanes: (1) microbial degradation that preferentially removed $n$ alkanes, or (2) alteration of organic matter during $\mathrm{Cu}$ mineralization. In order to test which of these processes altered organic matter in the lower Nonesuch Fm., it will be necessary to analyze organic matter from the same stratigraphic horizon (e.g., the "domino" shale) in mineralized and unmineralized areas.

The biomarker composition of one sample of the "domino" shale (412) was analyzed using MRM-GCMS (R.E. Summons, unpublished data, 1991). Homologous series of pentacyclic triterpanes and steranes were detected and quantified. Because of the absence of $n$ alkanes, the concentrations of biomarkers are high, but the composition is similar to unmineralized Nonesuch Fm. samples. The ratio of $\mathrm{C}_{29} \alpha \alpha \alpha$ sterane $20 \mathrm{~S} /(20 \mathrm{~S}+20 \mathrm{R})$ is 0.5 , close to the equilibrium value of 0.54 , and the same as the value for the "stripey" shale. The high thermal maturity of samples from the "domino" and "stripey" shales confirms the elevated thermal maturity at White Pine relative to unmineralized strata and is interpreted to result from the influx of hydrothermal fluids during main- and second-stage mineralization at White Pine.

\subsection{Relations among sulfur, copper and organic carbon}

5.6.1. Sulfur and organic carbon. Hieshima and Pratt (1991) interpreted positive covariance between $\mathrm{S}_{\text {tot }}$ and $\mathrm{C}_{\text {org }}$ in unmineralized Nonesuch Fm. strata as the product of microbially mediated sulfate reduction and subsequent pyrite formation during early diagenesis (Fig. 12a). At White Pine, the degree of deviation from the correlation observed in unmineralized rocks is stratigraphically dependent. In the "lower sandstone", $\mathrm{C}_{\text {org }}$ consists of petroleum and pyrobitumen, therefore sulfides derived from bacterial sulfate reduction during early diagenesis are not present. $S_{\text {tot }}$ in samples of the "domino" shale covaries with $\mathrm{C}_{\text {org }}$ (Fig. 12a). The slope of the relationship is significantly higher than that for unmineralized samples; however, the small number of samples and limited range of $\mathrm{C}_{\text {org }}$ in our sample set precludes definitive interpretation. Samples from the "stripey" shale contain uniform concentrations of $\mathrm{C}_{\mathrm{org}}$ and variable concentrations of $\mathrm{S}_{\mathrm{tot}}$ that are independent of $\mathrm{C}_{\text {org }}$. Chalcocitic samples of the "stripey" shale have the highest $S_{\text {tot }}$ values, consistent with petrographic observations suggesting that sulfur was added to this unit during second-stage mineralization.

5.6.2. Organic carbon-sulfur-copper relation- 

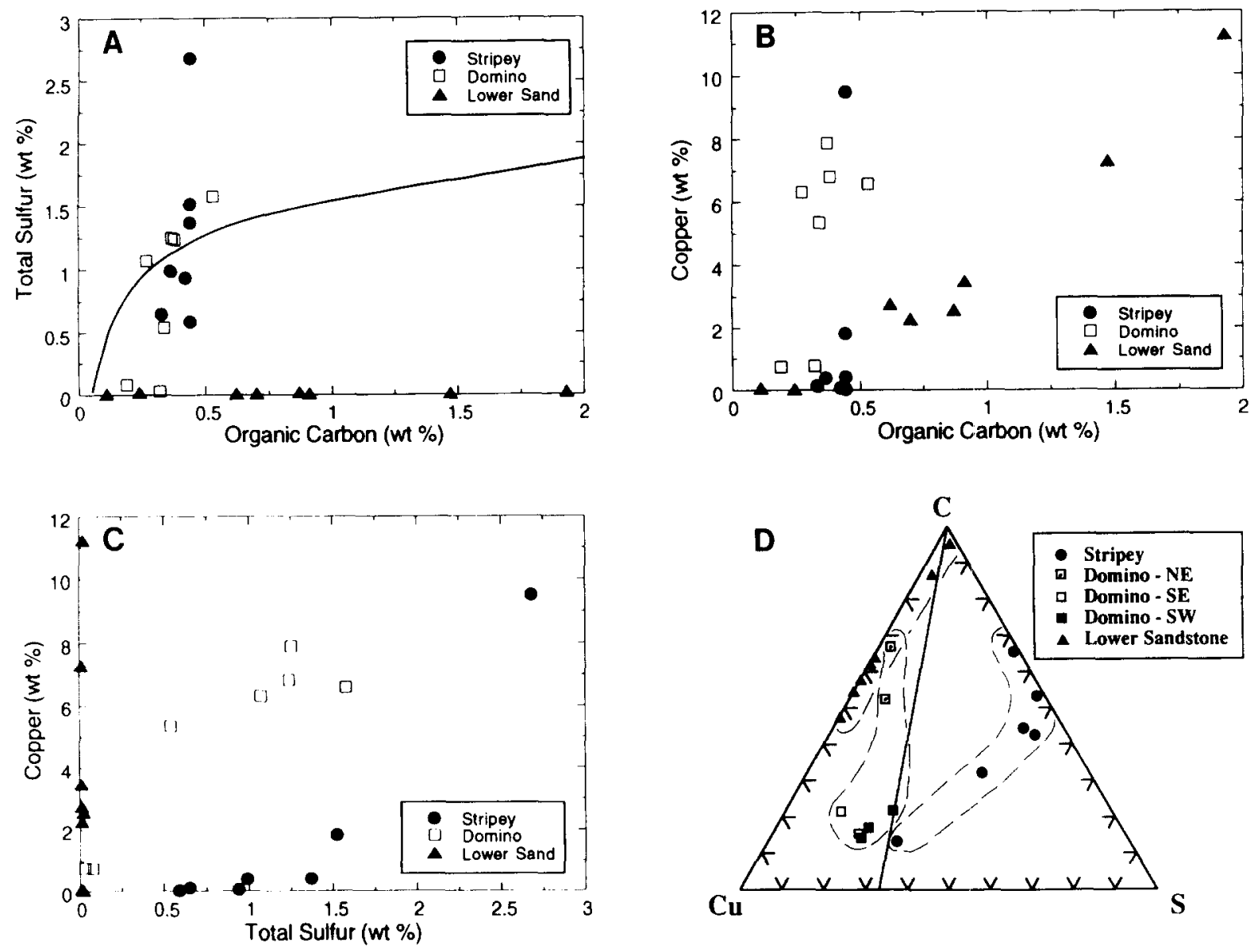

Fig. 12. A. $\mathrm{Wt} \% \mathrm{~S}_{\text {total }}$ vs. $\% \mathrm{C}_{\mathrm{org}}$. Solid line represents logarithmic regression for unmineralized samples presented by Hieshima and Pratt (1991).

B. $\mathrm{Wt} \% \mathrm{Cu}$ vs. $w t \% \mathrm{C}_{\text {org }}$.

C. $\mathrm{Wt} \% \mathrm{Cu}$ vs. $\mathrm{wt} \% \mathrm{~S}_{\text {total }}$.

D. Triangular diagram showing fields occupied by stratigraphic horizons in mole percent $\mathrm{C}_{\text {org }}-\mathrm{S}-\mathrm{Cu}$ space. Line represents the stoichiometric composition of chalcocite.

ships. Main- and second-stage mineralization have different characteristics. Textural evidence indicates Cu-bearing sulfides replaced pre-existing early-diagenetic pyrite during main-stage mineralization (e.g., Jost, 1968; Brown, 1971; Wiese, 1973; Sliney, 1988). However, Hoy and Ohmoto (1989) suggest that additional sulfur was added to the White Pine ore body by abiogenic precipitation of sulfides from an oxidized cupriferous brine, using organic matter as a reductant. During second-stage mineralization, pyrite in the "stripey" shale was locally altered to chalco- cite near compressional faults, and native $\mathrm{Cu}$ was deposited in the "lower sandstone" and "domino" shale. The chemical characteristics of main- and second-stage mineralization are recorded by relationships among $\mathrm{C}_{\mathrm{org}}, \mathrm{S}_{\mathrm{tot}}$ and $\mathrm{Cu}$.

Wiese (1973) noted positive correlations between $\mathrm{Cu}$ and $\mathrm{S}_{\mathrm{tot}}, \mathrm{Cu}$ and $\mathrm{C}_{\text {org }}$, and $\mathrm{S}_{\mathrm{tot}}$ and $\mathrm{C}_{\text {org }}$ in the "parting shale". The "domino" shale, which has locally experienced both mainand second-stage $\mathrm{Cu}$ mineralization, contains chalcocite as the dominant Cu-bearing mineral, so $\mathrm{Cu}$ correlates weakly with $\mathrm{S}_{\text {tot }}$ (Fig. 
$12 \mathrm{c}$ ). $\mathrm{Cu}$ is independent of $\mathrm{C}_{\mathrm{org}}$ in the "domino" shale (Fig. 12b). Relationships among $\mathrm{C}_{\text {org }}, \mathrm{S}_{\mathrm{tot}}$ and $\mathrm{Cu}$ in the "domino" shale are illustrated in a triangular diagram of these components. Samples of the "domino" shale lie parallel to the line representing the stoichiometric composition of chalcocite but are enriched in $\mathrm{Cu}$ by an average of $7 \mathrm{~mole} \%$, reflecting addition of native $\mathrm{Cu}$ during main- and second-stage mineralization. Relationships expressed in the triangular diagram indicate that samples of the "domino" shale from the southwestern and southeastern domains are enriched in $S_{t o t}$ and $\mathrm{Cu}$ relative to samples from the northeastern domain (Fig. 12d). We hypothesize that samples in the southern domains were enriched in $\mathrm{Cu}$ and $\mathrm{S}_{1 \mathrm{ot}}$ during second-stage mineralization.

$\mathrm{Cu}$ does not correlate with $\mathrm{C}_{\text {org }}$ in the "stripey" shale (Fig. 12b). However, chalcocitic samples do contain the highest $S_{\text {tot }}$ values (Fig. $12 \mathrm{c})$, and the mixing line between pyritic and chalcocitic samples trends down towards the $\mathrm{Cu}-\mathrm{S}$ join, suggesting that sulfur was added to the "stripey" shale during second-stage mineralization (Fig. 12d). Chalcocite occurs only in samples of the "stripey" shale that occur within $10-20 \mathrm{~m}$ of compressional faults, and therefore $\mathrm{Cu}$ and $\mathrm{S}_{\mathrm{tot}}$ are enriched only in these proximal samples. Apparently, second-stage mineralizing fluids did not alter the $S_{\text {tot }}$ contents of samples outside of this range.

Sulfides rarely occur in the "lower sandstone"; therefore $S_{\text {tot }}$ contents are extremely low (Fig. 12a and c). However, $\mathrm{Cu}$ correlates with $\mathrm{C}_{\text {org }}$, consistent with the hypothesis that native $\mathrm{Cu}$ was precipitated by oxidation of organic matter (Kelly and Nishioka, 1985; Fig. 12b). Brady (1960) and Hamilton (1967), on the basis of point counting, noted a similar relationship between vol\% $\mathrm{C}_{\text {org }}$ and vol\% $\mathrm{Cu}$ in the lower sand.

\section{Conclusions}

Organic matter and $\mathrm{Cu}$ mineralization are intimately associated at White Pine. Organic matter had both direct and indirect roles in precipitation of $\mathrm{Cu}$ during main- and secondstage mineralization. Early diagenesis of Nonesuch Fm. sediments included bacteriallymediated sulfate reduction and precipitation of pyrite. Hieshima and Pratt (1991) infer that pyrite formation was influenced by the concentrations of reactive iron minerals, favorable redox environments, and composition and quantity of organic matter. Relationships among organic $\mathrm{C}, \mathrm{S}$ and $\mathrm{Cu}$ are consistent with petrographic data, suggesting that main-stage mineralization occurred largely through the introduction of cupriferous fluids into the Nonesuch Fm. and alteration of pyrite to chalcocite (e.g., Brown, 1971; Wiese, 1973; Sliney, 1988 ).

Mineralization altered organic matter at White Pine. Indigenous bitumen from the "stripey" and "domino" shales is of significantly higher thermal maturity than bitumen from unmineralized upper Nonesuch Fm. strata in subjacent portions of the rift. Thermal anomalies related to main- and/or second-stage mineralization elevated the thermal maturity of White Pine organic matter despite relatively low temperatures $\left(<100^{\circ} \mathrm{C}\right)$. Bitumen from the "domino" shale is altered significantly because of mineralization and/or biodegradation. Pyrobitumen present as inclusions in veins and as cement in the "lower sandstone" may have formed as a result of oxidation of precursor petroleum during secondstage mineralization.

Active petroleum seeps display a trend in thermal maturity that mimics the intensity of second-stage hydrothermal activity in the mine area, suggesting that these petroleums were altered during compressional faulting and concomitant second-stage mineralization. However, the exact origin of these seeps remains enigmatic.

Second-stage mineralization at White Pine is associated spatially and temporally with compressional faulting that presumably coincided with reverse movement along the Kew- 
eenaw fault at $\sim 1060 \mathrm{Ma}$. Petroleum and pyrobitumen inclusions associated with compressional faults record the migration of petroleum into the White Pine region from hotter axial portions of the Midcontinent Rift during this tectonic event. Petroleum may have migrated synchronously with, or slightly before, influx of oxidized, metal-bearing brines and may have subsequently served as a source of reducing potential for precipitation of native $\mathrm{Cu}$ in the "lower sandstone".

\section{Acknowledgements}

We are grateful to the Copper Range Company for allowing access to the White Pine mine, and for providing copper assays. Dr. Roger E. Summons, Bureau of Mineral Resources, Canberra, Australia, generously provided MRM-GCMS data. We thank William C. Kelly, Lisa M. Pratt, Eileen S. Ho and Phillip A. Meyers for helpful discussions. Deborah Petersen assisted with sample preparation and analysis. Andrew Nyblade helped estimate possible heat flow for the Nonesuch Fm. William F. Cannon provided possible paleodepths of the Nonesuch Fm. during the thrusting event, and has provided critical insights into the regional geology of the Midcontinent Rift. Doreen A. Zaback, William C. Kelly and Richard M. Kettler improved early versions of the manuscript. Reviews by Wilhelm Püttmann and two anonymous reviewers led to significant improvements in the manuscript. This work has been supported, in part, by a grant from Amoco Oil Company and by DOE grant DE-FG02-88ER13978. Acknowledgement is made to the donors of The Petroleum Research Fund, administered by the American Chemical Society, for partial support of this research.

\section{References}

Barton. P.B. and Skinner, B.J., 1979. Sulfide mineral stabilities. In: H.L. Barnes (Editor), Geochemistry of
Hydrothermal Ore Deposits. Wiley, New York, N.Y., pp. 278-403.

Behrendt, J.C., Green, A.G., Cannon, W.F., Hutchinson, D.R., Lee, M.W., Milkereit, B., Agena, W.F. and Spencer, C., 1988. Crustal structure of the Midcontinent Rift System: Results from GLIMPCE deep seismic reflection profiles. Geology, 16:81-85.

Berner, R.A., 1984. Sedimentary pyrite formation: An update. Geochim. Cosmochim. Acta, 48: 605-618.

Birch, F., 1954. Thermal conductivity, climatic variation, and heat flow near Calumet, Michigan. Am. J. Sci., 252: $1-25$.

Boreham, C.J., Crick, I.H. and Powell, T.G., 1988. Alternative calibration of the Methylphenanthrene Index against vitrinite reflectance: Application to maturity measurements on oils and sediments. Org. Geochem., 12: 289-294.

Bornhorst, T.J., Paces, J.B., Grant, N.K., Obradovich, J.D. and Huber, N.K., 1988. Age of native copper mineralization, Keweenaw Peninsula, Michigan. Econ. Geol., 83: 619-625.

Brady, J.M., 1960. Ore and sedimentation of the lower sandstone, at the White Pine mine, Michigan. M.S. Thesis, Michigan Technological University, Houghton, Mich. (unpublished).

Brown, A.C., 1971. Zoning in the White Pine copper district, Ontonagon County, Michigan. Econ. Geol., 66: 543-573.

Burnie, S.W., Schwartz, H.P. and Crockett, J.H., 1972. A sulfur isotopic study of the White Pine mine, Michigan. Econ. Geol., 67: 895--914.

Cannon, W.F., Green, A.G., Hutchinson, D.R., Lee, M., Milkereit, B., Halls, H.C., Green, J.C., Dickas, A.B., Morey, G.B., Sutcliffe, R. and Spencer, C., 1989. The North American Midcontinent Rift beneath Lake Superior from GLIMPCE seismic reflection profiling. Tectonics, 8: 305-332.

Carpenter, R.H., 1963. Some vein-wall rock relationships in the White Pine mine, Ontonagon County, Michigan. Econ. Geol., 58: 643--666.

Chaudhuri, S. and Faure, G., 1967. Geochronology of the Keweenawan rocks, White Pine, Michigan. Econ. Geol., 62: 1011-1033.

Clarkson, G. and Reiter, M., 1984. Analysis of terrestrial heat-flow profiles across the Rio Grande Rift and southern Rocky Mountains in northern New Mexico. N.M. Geol. Soc., Guidebk., 35th Field Conf., pp. 3944.

Daniels, Jr., P.A., 1982. Upper Precambrian sedimentary rocks: Oronto Group, Michigan-Wisconsin. In: R.J. Wold and W.J. Hinze (Editors), Geology and Tectonics of the Lake Superior Basin. Geol. Soc. Am. Mem., 156: 107-133.

Davis, D.W. and Paces, J.B., 1990. Time resolution of geologic events on the Keweenaw Peninsula and implications for development of the Midcontinent Rift 
System. Earth Planet. Sci. Lett., 97: 54-64.

Decker, E.R., Bucher, G.J., Buelow, K.L. and Heasler, H.P., 1984. Preliminary interpretation of heat flow and radioactivity in the Rio Grande Rift Zone in central and northern Colorado. N.M. Geol. Soc., Guidebk., 35th Field Conf., pp. 45-50.

Dickas, A.B., 1988. The control of extrusion and sedimentary patterns within Keweenawan age structures of the Lake Superior Basin by taphrogenesis. In: M.S. Wollensak (Editor), Upper Keweenawan Rift-Fill Sequence, Mid-Continent Rift System, Michigan. Mich. Basin Geol. Soc., Guidebk., pp. 81-94.

Dickas, A.B. and Mudrey, Jr., M.G., 1989. Central North American case for segmented rift development. 28th Int. Geol. Congr., pp. 1-396-1-397 (abstract).

Eglinton, G., Scott, P.M., Belsky, T., Burlingame, A.L. and Calvin, M., 1964. Hydrocarbons of a biological origin from a 1-billion year old sediment. Science, 145: 262264.

Elmore, R.D., 1983a. Precambrian non-marine stromatolites in alluvial fan deposits, the Copper Harbor Conglomerate, upper Michigan. Sedimentology, 30: 829-842.

Elmore, R.D., 1983b. The Copper Harbor Conglomerate: A late Precambrian fining-upward alluvial fan sequence in northern Michigan. Geol. Soc. Am. Bull, 95: 610-617.

Elmore, R.D., Milavec, G.J., Imbus, S.W. and Engel, M.H., 1989. The Precambrian Nonesuch Formation of the North American Mid-Continent Rift, sedimentology and organic geochemical aspects of lacustrine deposition. Precambrian Res., 43: 191-213.

Ensign, Jr., C.O., White, W.S., Wright, J.C., Patrick, J.L., Leone, R.J., Hathaway, D.J., Trammell, J.W., Fritts, J.J. and Wright, T.L., 1968. Copper deposits in the Nonesuch Shale, White Pine, Michigan, In: J.D. Ridge (Editor), Ore Deposits of the United States 19331967, Vol. 1 (Graton-Sales Volume). Am. Inst. Min. Metall. Pet. Eng., New York, N.Y. pp. 459-488.

Freeman, K.H., Hayes, J.M., Trendel, J.M. and Albrecht, P., 1990. Evidence from carbon isotope measurements for diverse origins of sedimentary hydrocarbons. Nature (London), 343: 254-256.

Hamilton, S.K., 1967. Copper mineralization in the upper part of the Copper Harbor Conglomerate at White Pine, Michigan. Econ. Geol., 62: 885-904.

Hieshima, G.B. and Pratt, L.M., 1991. Sulfur/carbon ratios and extractable organic matter of the Middle Proterozoic Nonesuch Formation, North American Midcontinent Rift. Precambrian Res., 54: 65-79.

Hieshima, G.B., Pratt, L.M. and Hayes, J.M., 1990. Novel isotopic compositions of total organic carbon and bitumen in the Nonesuch Formation, North American Mid-Continent Rift. Am. Assoc. Pet. Geol. Bull., 74: 674 (abstract).

Hinze, W.J., Braile, L.W. and Chandler, V.W., 1990. A geophysical profile of the southern margin of the Midcontinent Rift System in western Lake Superior. Tectonics, 9: 303-310.

Ho, E.S., Meyers, P.A. and Mauk, J.L., 1990. Organic geochemical study of mineralization in the Keweenawan Nonesuch Formation at White Pine, Michigan. Org. Geochem., 16: 229-234.

Hoering, T.C., 1976. Molecular fossils from the Precambrian Nonesuch Shale. Carnegie Inst. Washington Yearbk., 75: 806-813.

Hoy, L.D. and Ohmoto, H., 1989. Constraints for the genesis of redbed-associated stratiform $\mathrm{Cu}$ deposits from sulphur and carbon mass-balance relations. In: R.W. Boyle, A.C. Brown, C.W. Jefferson, E.C. Jowett and R.V. Kirkham (Editors), Sediment-hosted Stratiform Copper Deposits. Geol. Assoc. Can., Spec. Pap., 36: $135-149$.

Imbus, S.W., Engel, M.H., Elmore, R.D. and Zumberge, J.E., 1988. The origin, distribution and hydrocarbon generation potential of organic-rich facies in the Nonesuch Formation, Central North American Rift System: A regional study. Org. Geochem., 13: 207-219.

Jost, M., 1968. The White Pine copper district: Mineralogical investigation and genetic interpretation. Ph.D. Dissertation, Johannes Gutenberg University, Mainz (unpuplished).

Kalliokoski, J., 1982. Jacobsville Sandstone In: R.J. Wold and W.J. Hinze (Editors), Geology and Tectonics of the Lake Superior Basin. Geol. Soc. Am. Mem., 156: 147-156.

Kelly, W.C. and Nishioka, G.K., 1985. Precambrian oil inclusions in late veins and the role of hydrocarbons in copper mineralization at White Pine, Michigan. Geology, 13: 334-337.

Leventhal, J.S., 1986. Roles of organic matter in ore deposits, In: W.E. Dean (Editor), Organics and Ore Deposits. Denver Reg. Explor. Geol. Soc., Denver, Colo., pp. 7-20.

Ludwig, K.R., 1990. Isoplot: A plotting and regression program for radiogenic-isotope data, for IBM-PC compatible computers: U.S. Geol. Surv., Open-File Rep. 88-557, Rev. of March 7, 1990, 44 pp.

Machel, H.G., 1989. Relationships between sulfate reduction and oxidation of organic compounds to carbonate diagenesis, hydrocarbon accumulations, salt domes, and metal sulfide deposits. Carbonates Evaporites, 4: $137-151$.

Mauk, J.L., Seasor, R.W., Kelly, W.C. and van der Pluijm, B.A., 1989. The relationship between structure and second-stage copper mineralization in the White Pine district of the Midcontinent Rift, northern Michigan. Geol. Soc. Am., Abstr. Prog., 21: Al 30 (abstract).

McGinnis, L.D., 1990. Lake Superior rift basins. Eos (Trans Am. Geophys. Union), 71: 995 (abstract).

Meinschein, W.G., Barghoorn, E.S. and Schopf, J.W., 1964. Biological remnants in a Precambrian sediment. Science, 145: 262-263. 
Morgan, P., 1982. Heat flow in rift zones. In: G. Palmason (Editor), Continental and Oceanic Rifts. Geodynamics Series, V. 8. Am. Geophys. Union, Washington, D.C., pp. 107-122.

Nishioka, G.K., 1983. Origin of late veins in the White Pine copper deposit, northern Michigan. M.S. Thesis, University of Michigan, Ann Arbor, Mich. (unpublished).

Ohmoto, H. and Lasaga, A.C., 1982. Kinetics of reactions between aqueous sulfates and sulfides in hydrothermal systems. Geochim. Cosmochim. Acta, 46: $1727-$ 1745.

Peter, J.M., Peltonen, P., Scott, S.D., Simoneit, B.R.T. and Kawka, O.E., 1991. ${ }^{14} \mathrm{C}$ ages of hydrothermal petroleum and carbonate in Guaymas Basin, Gulf of California: Implications for oil generation, expulsion and migration. Geology, 19:253-256.

Pratt, L.M., Summons, R.E. and Hieshima, G.B., 1991. Sterane and triterpane biomarkers in the Precambrian Nonesuch Formation, North American Midcontinent Rift. Geochim. Cosmochim. Acta, 55: 911-916.

Püttmann, W. and Gobel, ,W., 1990. The Permian Kupferschiefer of southwest Poland: a geochemical trap for migrating, metal-bearing solutions. Appl. Geochem., 5: $227-235$

Püttmann, W., Hagemann, H.W., Merz, C. and Speczik, S., 1988. Influence of organic material on mineralization processes in the Permian Kupferschiefer Formation, Poland. Org. Geochem., 13: 357-363.

Püttmann, W., Merz, C. and Speczik, S., 1989. The secondary oxidation of organic material and its influence on Kupferschiefer mineralization of southwest Poland. Appl. Geochem., 4: 151-161.

Radke, M. and Welte, D.H., 1983. The Methylphenanthrenen Index (MPI): A maturity parameter based on aromatic hydrocarbons. In: M. Bjorøy, P. Albrecht, C. Cornford, et al. (Editors), Advances in Organic Geochemistry 1981. Wiley, Chichester, pp. 504-512.

Roy, R.F., 1963. Heat flow measurements in the United States. Ph.D. Thesis, Harvard University, Cambridge, Mass. (unpublished).
Ruiz, J., Jones, L.M. and Kelly, W.C., 1984. Rubidiumstrontium dating of ore deposits hosted by Rb-rich rocks, using calcite and other common Sr-bearing minerals. Geology, 12: 259-262.

Simoneit, B.R.T., 1990. Petroleum generation, an easy and widespread process in hydrothermal systems: an overview. Appl. Geochem., 5: 3-15.

Sliney, R.E., 1988. Comparative mineralogy and geochemistry of a stratigraphic unit within the upper shale member of the Nonesuch Formation, White Pine, Michigan. M.S. Thesis, University of Michigan, Ann Arbor, Mich. (unpublished).

Steiger, R.H. and Jäger, E., 1977. Subcommission on Geochronology: Convention on the use of decay constants in geo- and cosmo-chronology. Earth Planet. Sci. Lett., 36: 359-362.

Trudinger, P.A. Chambers, L.A. and Smith, J.W., 1985. Low-temperature sulphate reduction: biological versus abiological. Can. J. Earth Sci., 22: 1910-1918.

White, W.S., 1960. The White Pine copper deposit. Econ. Geol., 55: 402-410.

White, W.S., 1968. The native copper deposits of northern Michigan. In: J.D. Ridge (Editor), Ore Deposits of the United States 1933-1967, Vol. 1 (Graton-Sales Volume). Am. Inst. Min. Metall. Pet. Eng., New York, N.Y., pp. 303-325.

White, W.S., 1971. A paleohydrologic model for the mineralization of the White Pine copper deposit, northern Michigan. Econ. Geol, 66: 1-13.

White, W.S. and Wright, J.C., 1954. The White Pine copper deposit, Ontonagon County, Michigan. Econ. Geol., 49: 675-716.

White, W.S. and Wright, J.C., 1966. Sulfide mineral zoning in the basal Nonesuch Shale, northern Michigan. Econ. Geol., 61: 1171-1190.

Wiese, Jr., R.G., 1973. Mineralogy and geochemistry of the Parting Shale, White Pine, Michigan. Econ. Geol., 68: 317-331. 